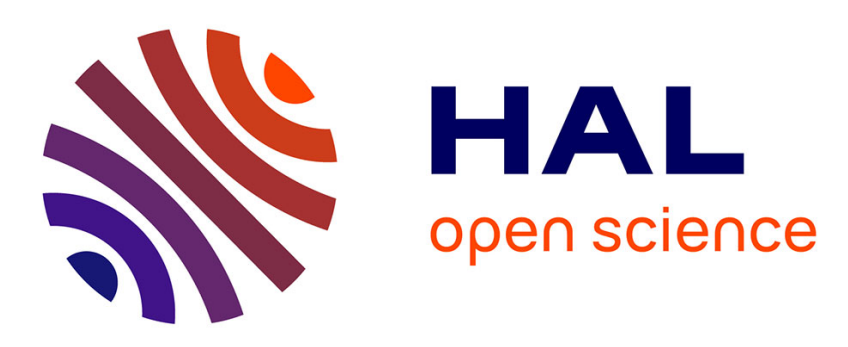

\title{
Osmocenyl-tamoxifen derivatives target the thioredoxin system leading to a redox imbalance in Jurkat cells
} Valeria Scalcon, Siden Top, Hui Zhi Shirley Lee, Anna Citta, Alessandra

Folda, Alberto Bindoli, Weng Kee Leong, Michèle Salmain, Anne Vessières, Gérard Jaouen, et al.

\section{To cite this version:}

Valeria Scalcon, Siden Top, Hui Zhi Shirley Lee, Anna Citta, Alessandra Folda, et al.. Osmocenyltamoxifen derivatives target the thioredoxin system leading to a redox imbalance in Jurkat cells. Journal of Inorganic Biochemistry, 2016, 160, pp.296-304. 10.1016/j.jinorgbio.2016.04.005 . hal01313082

\section{HAL Id: hal-01313082 \\ https://hal.sorbonne-universite.fr/hal-01313082}

Submitted on 9 May 2016

HAL is a multi-disciplinary open access archive for the deposit and dissemination of scientific research documents, whether they are published or not. The documents may come from teaching and research institutions in France or abroad, or from public or private research centers.
L'archive ouverte pluridisciplinaire HAL, est destinée au dépôt et à la diffusion de documents scientifiques de niveau recherche, publiés ou non, émanant des établissements d'enseignement et de recherche français ou étrangers, des laboratoires publics ou privés. 


\section{Osmocenyl-tamoxifen derivatives target the thioredoxin system leading to a redox imbalance in Jurkat cells}

Valeria Scalcon, ${ }^{\mathrm{a}, \mathrm{b}^{*}}$ Siden Top, ${ }^{\mathrm{c}, \mathrm{d}^{*}}$ Hui Zhi Shirley Lee, ${ }^{\mathrm{c}, \mathrm{d}, \mathrm{e}, \mathrm{f}}$ Anna Citta ${ }^{\mathrm{b}}$, Alessandra Folda ${ }^{\mathrm{b}}$, Alberto Bindoli, ${ }^{\mathrm{a}}$ Weng Kee Leong, ${ }^{\mathrm{f}}$, Michèle Salmain, ${ }^{\mathrm{c}, \mathrm{d}}$ Anne Vessières, ${ }^{\mathrm{c}, \mathrm{d}}$ Gérard Jaouen, ${ }^{\mathrm{c}, \mathrm{e},{ }^{* * *}}$ Maria Pia Rigobello, ${ }^{\text {b** }}$

a) Istituto di Neuroscienze (CNR) Sezione di Padova, c/o Dipartimento di Scienze Biomediche, Via Ugo Bassi 58/b, 35131 Padova, Italy.

b) Dipartimento di Scienze Biomediche, Università di Padova, Via Ugo Bassi 58/b, 35131 Padova, Italy.

c) Sorbonne Universités, UPMC Univ Paris 06, UMR 8232, IPCM, F-75005 Paris, France

d) CNRS, UMR 8232, IPCM, F-75005 Paris, France

e) Chimie ParisTech, 11 rue Pierre et Marie Curie, F-75005 Paris, France

f) Division of Chemistry \& Biological Chemistry, Nanyang Technological University, 21 Nanyang Ling, Singapore 637371

* Valeria Scalcon and Siden Top: these authors contributed equally

** Gérard Jaouen and Maria Pia Rigobello: co- corresponding authors

\section{Keywords}

Osmocene, osmocenyl-tamoxifen, thioredoxin reductase, ROS, Jurkat cancer cells 


\section{ABSTRACT:}

To complete our study of the iron, ruthenium and osmium metallocene triad derived from hydroxytamoxifen, we report here the synthesis and study of the biological effects of two ferrocifen analogs in the osmium series, namely the monophenolic complex 1, the tamoxifen-like complex 2 and their oxidized quinone methide derivatives, 1-QM and 2-QM. Studies carried out in vitro on purified thioredoxin reductase (TrxR) show that the characteristic inhibition of TrxR is observed with $\mathbf{1}$ and 2 only after their enzymatic oxidation by the $\mathrm{H}_{2} \mathrm{O}_{2} / \mathrm{HRP}$ system. The observed inhibition is very similar for the two complexes $\left(\mathrm{IC}_{50}=2.4\right.$ and $1.2 \mu \mathrm{M}$ for $\mathbf{1}$ and 2 after treatment by $\left.\mathrm{HRP} / \mathrm{H}_{2} \mathrm{O}_{2}\right)$ but different from that obtained with the corresponding quinone methides $\left(\mathrm{IC}_{50}=5.4\right.$ and $3.6 \mu \mathrm{M}$ for 1-QM and 2QM). The UV spectra of 1 or $\mathbf{2}$ incubated in the presence of $\mathrm{HRP} / \mathrm{H}_{2} \mathrm{O}_{2}$ show that the species generated by enzymatic oxidation is not a quinone methide but more probably its corresponding cation. On Jurkat cells, complexes 1 and 2 behave differently. Indeed, while 2 shows high toxicity $\left(\mathrm{IC}_{50}=7.4 \mu \mathrm{M}\right)$, that of 1 is much more modest $\left(\mathrm{IC}_{50}=42 \mu \mathrm{M}\right)$. Interestingly, a significant inhibition of TrxR activity is observed in cells incubated with 2 (about $70 \%$ inhibition for incubation in the presence of $15 \mu \mathrm{M}$ ) while that induced by $\mathbf{1}$ is much weaker (about $30 \%$ inhibition for incubation in the presence of 50 $\mu \mathrm{M})$. This strong inhibition of TrxR activity induced by 2 leads to accumulation of thioredoxin and peroxiredoxin 3 in oxidized form as well as a significant decrease of the mitochondrial membrane potential (MMP). These results show that the cytotoxicity of the osmocifens depends on their oxidation within the cell and that inhibition of thioredoxin reductase is a key factor in rationalizing the cytotoxicity of these complexes on Jurkat cells.

\section{INTRODUCTION}

Owing to the poor outcomes seen in the treatment of a number of cancers such as glioblastoma, melanomas, ovarian and pancreatic cancers etc., the search for new active principles outside the established avenues is a burning current concern. For this reason, the unusual mechanistic properties of organometallic medicinal chemistry are presently the subject of an exponentially growing number of studies [1]. These entities offer inventive strategic approaches [2-6] in terms of optimized space filling, intracellular redox behavior and antitumoral activity, with pharmacophores possessing varied and multiple targeting options that make it possible to counteract the phenomena of resistance to proapoptotic stimuli [7]. To that can be added the variety of available metals [2] and, for the transition elements, the potential availability of several degrees of oxidation. 
With organometallic complexes of gold $[8,9]$, those from the group 8 triad, particularly of Fe and Ru, are amongst the most widely studied [10-13] with the notable exception to date of Os [14-17]. This heavy element offers a capacity for good stabilization of certain high degrees of oxidation (+VI) and for an excellent metal-to-ligand back-donation at low oxidation states (+II, +III) leading to more stable complexes than those of $\mathrm{Fe}$ or $\mathrm{Ru}$ in biological media. The potential of this so far neglected metal in biomedically-oriented organometallic complexes deserves to be better studied especially when comparisons with neighboring series of $\mathrm{Fe}$ and $\mathrm{Ru}$ are easy to obtain $[18,19]$.

Amongst the promising derivatives of ferrocene, the ferrocifen series, derived initially from tamoxifen, the drug used to combat hormone-dependent breast cancers, has been the subject of a number of studies [20-22]. These organometallic species can operate on cancerous cells via the signaling pathways of senescence $[23,24]$ or apoptosis, with markedly different effects depending on the concentration at which they are used and the type of cell involved, while healthy cells are affected only slightly or not at all [25].

Ferrocifen equivalents in the Ru and Os series (mono- and diphenolic, and tamoxifen-like) have recently been proved possible to synthesize $[19,26]$. Their electrochemical behavior as well as their cytotoxicity on breast cancer cells (MDA-MB-231 and MCF-7) have also been studied. In the two series, the tamoxifen-like complexes have high cytotoxicity while the phenolic complexes have much more modest cytotoxicity. This result is very different from that of the ferrocene analogs which have similar high cytotoxicities. In addition, unlike ferrocifens, where the active metabolite has been identified as being a quinone methide $[27,28]$, with these heavy metals the electrochemical signature of a quinone methide has not been found. Studies previously carried out on the chemical and biochemical properties of these complexes (lipophilicity, solubility and rate of formation of quinone methides, differences in the acidity of the phenolic protons) have not been able to elucidate their mechanism of action [26].

In cells, the thiol redox balance and removal of hydrogen peroxide and other hydroperoxides is exerted by the thioredoxin and glutathione systems. To remove hydrogen peroxide these systems utilize glutathione peroxidase and peroxiredoxin, respectively [29]. Of note, both glutathione peroxidase and thioredoxin reductase contain a selenocysteine residue at their catalytic site. In particular, thioredoxin reductase which is present in two isoforms, a cytosolic (TrxR1) and a mitochondrial one (TrxR2), is endowed with a C-terminal motif Cys-SeCys-Gly. In this sequence, selenocysteine is considered the 
major reactive site of the molecule towards metals, metal complexes and electrophilic organic compounds all able to inhibit the enzyme activity at micro/submicromolar concentrations [30]. In fact, the selenocysteine residue possesses a low pKa (5.24) that enhances its nucleophilic properties towards the above mentioned classes of compounds [31].

The recent study of thioredoxin reductases as possible targets of the ferrocifens has allowed new perspectives concerning their mechanism of action [32]. In the present paper, we examine the biological effects of two osmocifens, namely the monophenolic and the tamoxifen-like complexes 1 and 2, their oxidized derivatives obtained after enzymatic oxidation, and their corresponding quinone methides obtained by chemical oxidation (Chart 1). In particular, their effects on thioredoxin reductases both isolated and obtained from treated cancer cells, the redox state of thiol enzymes and the effects on ROS production and mitochondrial bioenergetics were considered. Inhibition of thioredoxin reductase seems to play a critical role in inducing the observed cytotoxic effects exerted by $\mathbf{1}$ and $\mathbf{2}$ in cultured cancer cells.

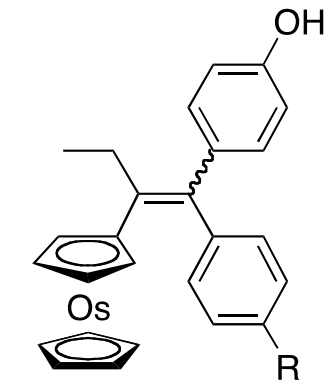

1: $\mathrm{R}=\mathrm{H}$

2: $\mathrm{R}=\mathrm{O}\left(\mathrm{CH}_{2}\right)_{3} \mathrm{NMe}_{2}$

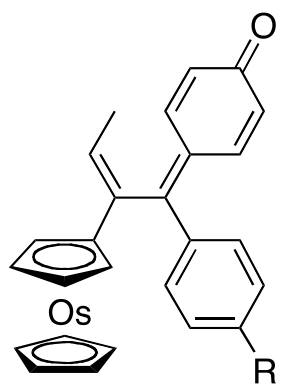

$1-Q M: R=H$

2-QM : $\mathrm{R}=\mathrm{O}\left(\mathrm{CH}_{2}\right)_{3} \mathrm{NMe}_{2}$

Chart 1 : Osmocifens (monophenol and tamoxifen-like osmium complexes)

\section{MATERIALS AND METHODS}

\subsection{Synthesis of 1,2 and of their corresponding QMs}

General remarks: All reactions and manipulations were carried out under an argon atmosphere using standard Schlenk techniques. Prior to use, acetone was dried over $\mathrm{CaCl}_{2}$, and pentane was dried over $4 \AA$ molecular sieves. $\mathrm{Ag}_{2} \mathrm{O}$ was freshly prepared according to the literature procedure [33]. ${ }^{1} \mathrm{H}$ and ${ }^{13} \mathrm{C}$-NMR spectra were acquired on a Bruker $300 \mathrm{MHz}$ spectrometer. Mass spectrometry was carried out at the "Service de Spectrométrie de Masse" at ENSCP, Paris. Elemental analysis and HRMS determinations were performed by the Laboratory of Microanalysis and the Small Molecule 
Mass Spectrometry Platform of IMAGIF (Centre de Recherche de Gif www.imagif.cnrs.fr). ICP-OES analysis were performed on the on a JY2000 apparatus (Jobin-Yvon Horiba) of the Metis Laboratory of the University Pierre et Marie Curie. Complexes $\mathbf{1}$ and $\mathbf{2}$ were prepared as previously described [26].

\subsubsection{QM of 1-phenyl-1-(hydroxyphenyl)-2-osmocenyl-but-1-ene (1-QM)}

$1(60 \mathrm{mg}, 0.11 \mathrm{mmol})$ was dissolved in dry acetone $(5 \mathrm{~mL}) . \mathrm{Ag}_{2} \mathrm{O}(154 \mathrm{mg}, 0.66 \mathrm{mmol})$ was added and the mixture was stirred for $2 \mathrm{~h}$ at room temperature. The red solution of quinone methide formed was separated from the solid by centrifugation (room temperature, $400 \mathrm{~g}, 5 \mathrm{~min}$ ) and evaporated. A red oil (53 mg, 89\% yield) of quinone methide was obtained. $1 \mathrm{~mL}$ of acetone was added to dissolve the quinone methide. Pentane was added to precipitate the quinone methide (red solid), $\mathrm{Z}+\mathrm{E}$ isomers; $\mathrm{E}$ isomer is supposed to be the major isomer (E:Z 73:27). ${ }^{1} \mathrm{H}$ NMR $\left(300 \mathrm{MHz}, \mathrm{CD}_{3} \mathrm{COCD}_{3}\right) \delta: 1.59$ (d, $3 \mathrm{H}, J=7.0 \mathrm{~Hz}, \mathrm{CH}_{3}$, major isomer), 1.99 (d, $J=7.0 \mathrm{~Hz}, 3 \mathrm{H}, \mathrm{CH}_{3}$, minor isomer), 4.50 (s, $5 \mathrm{H}, \mathrm{C}_{5} \mathrm{H}_{5}$, major isomer), $4.50-4.64\left(\mathrm{~m}, 4 \mathrm{H}_{1} \mathrm{C}_{5} \mathrm{H}_{4}\right), 4.64\left(\mathrm{~s}, 5 \mathrm{H}, \mathrm{C}_{5} \mathrm{H}_{5}\right.$, minor isomer), $5.75(\mathrm{q}, J=7.0 \mathrm{~Hz}, 1 \mathrm{H}$, C$-\mathrm{He}$, minor isomer), 6.28 (q, $J=7.0 \mathrm{~Hz}, 1 \mathrm{H}, \mathrm{C} \underline{\mathrm{H}}-\mathrm{Me}$, major isomer), 6.30-6.39 (m, 2H, $\left.\mathrm{C}_{6} \mathrm{H}_{4}\right), 7.33$ (dd, $J=10.0 \mathrm{~Hz}+J=2.5 \mathrm{~Hz}, 1 \mathrm{H}, \mathrm{C}_{6} \mathrm{H}_{4}$, minor isomer), 7.40-7.53 (m, 7H, $\left.\mathrm{C}_{6} \mathrm{H}_{5}+\mathrm{C}_{6} \mathrm{H}_{4}\right) .{ }^{13} \mathrm{C} \mathrm{NMR}$ $\left(75.47 \mathrm{MHz}, \mathrm{CD}_{3} \mathrm{COCD}_{3}\right) \delta: 15.8\left(\mathrm{CH}_{3}\right), 63.6+64.0+64.566 .5\left(\mathrm{C}_{5} \mathrm{H}_{4}\right), 65.8\left(\mathrm{C}_{5} \mathrm{H}_{5}\right.$, major isomer), $66.0\left(\mathrm{C}_{5} \mathrm{H}_{5}\right.$, minor isomer), $85.7\left(\mathrm{C}, \mathrm{C}_{5} \mathrm{H}_{5}\right), 125.2\left(\mathrm{CH}_{3}-\underline{\mathrm{CH}}=\mathrm{C}\right), 129.2,129.4,130.7,131.6,132.1$, $139.9\left(\underline{\mathrm{CH}}\right.$ of $\mathrm{C}_{6} \mathrm{H}_{5}$ and $\left.\mathrm{C}_{6} \mathrm{H}_{4}\right), 138.4(\mathrm{C}), 139.1(\mathrm{C}), 140.0(\mathrm{C}), 157.3(\mathrm{C}), 186.8(\mathrm{C}=\mathrm{O})$. EI-MS: 542.3 $[\mathrm{M}]{ }^{+}$HRMS (ESI, [ $\left.\mathrm{C}_{26} \mathrm{H}_{22} \mathrm{OOs}+\mathrm{H}\right]^{+}$) calcd: 543.1359, found: 543.1338. Anal. Calc. for $\mathrm{C}_{26} \mathrm{H}_{22} \mathrm{OO}$.0.5acetone (\%): C, 57.97; H, 4.42. Found: C, 58.06; H, 4.

\subsubsection{QM of 1-[(4-(3-dimethylaminopropoxy)phenyl)]-1-(hydroxyphenyl)-2-osmocenyl-but-1-ene (2-} QM)

$2(71 \mathrm{mg}, 0.11 \mathrm{mmol})$ was dissolved in dry acetone $(10 \mathrm{~mL}) . \mathrm{Ag}_{2} \mathrm{O}(154 \mathrm{mg}, 0.66 \mathrm{mmol})$ was added and the mixture was stirred for $2 \mathrm{~h}$ at room temperature. The red solution of quinone methide formed was separated from the solid by centrifugation (room temperature, $400 \mathrm{~g}, 5 \mathrm{~min}$ ) and evaporated. A red oil $(63 \mathrm{mg}, 90 \%$ yield) of quinone methide was obtained. $1 \mathrm{~mL}$ of acetone was added to dissolve the quinone methide. Pentane was added to precipitate the quinone methide (red solid). ${ }^{1} \mathrm{H}$ NMR (300 $\mathrm{MHz}, \mathrm{CD}_{3} \mathrm{COCD}_{3}$ ): $\delta 1.54\left(\mathrm{~d}, J=7.0 \mathrm{~Hz}, 3 \mathrm{H}, \mathrm{CH}_{3}\right), 1.93\left(\mathrm{~m}, 2 \mathrm{H}, \mathrm{CH}_{2}\right), 2.17$ (s, 6H, $\mathrm{NMe}_{2}$ ), 2.41 (t, $J$ $\left.=6.9 \mathrm{~Hz}, 2 \mathrm{H}, \mathrm{CH}_{2}\right), 4.14\left(\mathrm{t}, J=6.4 \mathrm{~Hz}, 2 \mathrm{H}, \mathrm{OCH}_{2}\right), 4.27\left(\right.$ broad s, $\left.1 \mathrm{H}, \mathrm{C}_{5} \mathrm{H}_{4}\right), 4.53\left(\mathrm{~s}, 5 \mathrm{H}, \mathrm{C}_{5} \mathrm{H}_{5}\right), 4.53-$ $4.66\left(\mathrm{~m}, 2 \mathrm{H}, \mathrm{C}_{5} \mathrm{H}_{4}\right), 4.97$ (broad s, 1H, $\left.\mathrm{C}_{5} \mathrm{H}_{4}\right), 6.27$ (q, $\left.J=7.0 \mathrm{~Hz}, 1 \mathrm{H}, \mathrm{C} \underline{\mathrm{H}}-\mathrm{Me}\right), 6.27-6.36(\mathrm{~m}, 2 \mathrm{H}$, 
$\left.\mathrm{C}_{6} \mathrm{H}_{4}\right), 7.08\left(\mathrm{~d}, J=8.8 \mathrm{~Hz}, 2 \mathrm{H}, \mathrm{C}_{6} \mathrm{H}_{4}\right), 7.38\left(\mathrm{~d}, \mathrm{~J}=8.8 \mathrm{~Hz}, 2 \mathrm{H}, \mathrm{C}_{6} \mathrm{H}_{4}\right), 7.41(\mathrm{dd}, J=10.0$ and $2.8 \mathrm{~Hz}$, $\left.1 \mathrm{H}, \mathrm{C}_{6} \mathrm{H}_{4}\right), 7.51$ (q, $J=10.0$ and $\left.2.8 \mathrm{~Hz}, 1 \mathrm{H}, \mathrm{C}_{6} \mathrm{H}_{4}\right) .{ }^{13} \mathrm{C} \mathrm{NMR}\left(75.46 \mathrm{MHz}, \mathrm{CD}_{3} \mathrm{COCD}_{3}\right) \delta: 15.7\left(\mathrm{CH}_{3}\right)$,

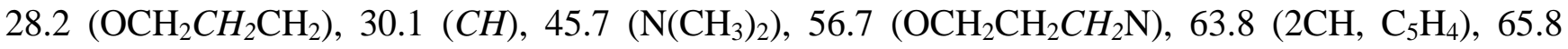
(7CH, $\left.\mathrm{C}_{5} \mathrm{H}_{5}+\mathrm{C}_{5} \mathrm{H}_{4}\right), 67.1\left(\mathrm{OCH}_{2} \mathrm{CH}_{2} \mathrm{CH}_{2} \mathrm{~N}\right), 115.4\left(2 \mathrm{CH}, \mathrm{C}_{6} \mathrm{H}_{4}\right), 125.4\left(\mathrm{CH}_{3}-\underline{\mathrm{CH}}=\mathrm{C}\right), 128.7(\mathrm{CH})$,

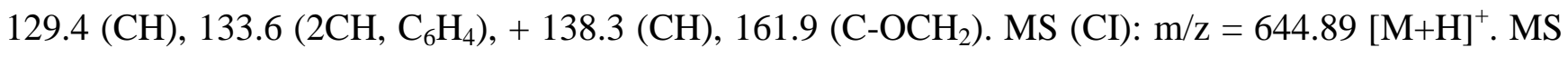
(CI): $\mathrm{m} / \mathrm{z}=644.89[\mathrm{M}+\mathrm{H}]^{+}$. HRMS (ESI, $\left[\mathrm{C}_{31} \mathrm{H}_{33} \mathrm{O}_{2} \mathrm{Os}+\mathrm{H}\right]^{+}$) calcd: 644.2200, found: 644.2187. Anal. Calc. for $\mathrm{C}_{31} \mathrm{H}_{33} \mathrm{NO}_{2}$ Os.0.5acetone (\%): C, 58.19; $\mathrm{H}, 4.41 ; \mathrm{N}, 2.09$. Found: C, 58.31; H, 5.11; N, 2.05 .

For biochemical experiments, $10 \mathrm{mM}$ stock solutions of 1, 2, 1-QM and 2-QM in DMSO were prepared just prior to use.

\subsection{TrxR1 preparation and enzymatic activity assay}

Highly purified cytosolic thioredoxin reductase (TrxR1) was prepared from rat liver according to the method of Luthman and Holmgren [34] and the protein content was measured according to Lowry et al. [35]. Thioredoxin reductase activity was determined by estimating the DTNB-reducing property of the enzyme in the presence of NADPH. Aliquots of highly purified TrxR1 $(60 \mathrm{nM})$ in 0.2 $\mathrm{M}$ Tris $\mathrm{HCl}$ buffer ( $\mathrm{pH} 8.1$ ), $1 \mathrm{mM}$ EDTA, and $0.25 \mathrm{mM}$ NADPH were preincubated for 5 min with the various compounds, at $25{ }^{\circ} \mathrm{C}$. The reaction was started with $1 \mathrm{mM}$ DTNB and followed spectrophotometrically at $412 \mathrm{~nm}$ for about $10 \mathrm{~min}$. TrxR2 activity was assayed with the same procedure.

\subsection{Enzymatic oxidation of 1 and 2 by the $\mathrm{H}_{2} \mathrm{O}_{2} / \mathrm{HRP}$ system}

Complexes 1 or 2 were incubated at a concentration of $25 \mu \mathrm{M}$ at $25{ }^{\circ} \mathrm{C}$ in $1 \mathrm{~mL}$ of $0.2 \mathrm{M}$ Tris $\mathrm{HCl}$ buffer $\left(\mathrm{pH}\right.$ 8.1), $1 \mathrm{mM}$ EDTA, 2.5\% DMSO with a solution of $22 \mathrm{nM}$ HRP and $0.1 \mathrm{mM} \mathrm{H}_{2} \mathrm{O}_{2}$. Kinetics of the reaction was monitored by UV-VIS spectrometry on a Cary 50 spectrometer (Varian).

\subsection{Cell cultures}

Jurkat cells were grown at $37{ }^{\circ} \mathrm{C}$ in a 5\% carbon dioxide atmosphere using RPMI 1640 medium containing $10 \%$ fetal calf serum and supplemented with $2 \mathrm{mM} \mathrm{L-glutamine.}$ 


\subsection{MTT assay}

Cell viability was determined with the MTT reduction assay. Jurkat cells $\left(8 \times 10^{4}\right)$ were treated with increasing concentrations of osmocifens for $24 \mathrm{~h}$. At the end of incubation, cells were treated for 3 h at $37{ }^{\circ} \mathrm{C}$ with $0.5 \mathrm{mg} / \mathrm{mL}$ MTT dissolved in PBS buffer. Afterward, $20 \mu \mathrm{L}$ of stop solution (50\% dimethylformamide, $20 \% \mathrm{SDS}, 2 \%$ acetic acid and $25 \mathrm{mM} \mathrm{HCl} \mathrm{pH} \mathrm{4.7)} \mathrm{were} \mathrm{added} \mathrm{to} \mathrm{each} \mathrm{well.} \mathrm{After}$ $15 \mathrm{~min}$, the absorbance at $595 \mathrm{~nm}$ was estimated using a plate reader (Tecan Infinite® M200 PRO).

\subsection{ICP-OES analysis}

Jurkat cells were incubated for $24 \mathrm{~h}$ in the presence of $50 \mu \mathrm{M}$ of 1 or $15 \mu \mathrm{M}$ of 2 and washed twice in PBS buffer. Pellets of cells $\left(10^{7}\right.$ cells) were suspended in $0.5 \mathrm{~mL}$ of $\mathrm{HCl}(37 \%$, Fluka for trace analysis) and digested at $60^{\circ} \mathrm{C}$ in an ultrasound bath for $1 \mathrm{~h}$. Then the samples were adjusted to $\mathrm{HCl} 2 \%$ by addition of $8.75 \mathrm{~mL}$ of water and filtered on a $0.2 \mu \mathrm{m}$ filter. Quantification of osmium was performed at $225.585 \mathrm{~nm}$. The results are the mean of 3 measurements. $\mathrm{HCl}$ was used instead of $\mathrm{HNO}_{3}$ classically used for ICP-OES experiments as $\mathrm{HNO}_{3}$ leads to the formation of the very toxic and volatile $\mathrm{OsO}_{4}$.

\subsection{Thioredoxin reductase and glutathione reductase assays in Jurkat cell lysates}

Jurkat cells $\left(2 \times 10^{6}\right)$ were incubated with 1 and 2 for $18 \mathrm{~h}$. After incubation cells were harvested and washed with PBS buffer. Each sample was lysed with a modified RIPA buffer containing $150 \mathrm{mM}$ $\mathrm{NaCl}, 50 \mathrm{mM}$ Tris $\mathrm{HCl}$ (pH 7.4), 1 mM EDTA, 1\% TRITON, 0.1\% SDS, 0.5\% DOC, $1 \mathrm{mM} \mathrm{NaF,} 0.1$ mM PMSF and an antiprotease cocktail ("Complete" Roche, Mannheim, Germany). After 40 min of incubation at $0{ }^{\circ} \mathrm{C}$, lysates were centrifuged at $14000 \mathrm{~g}$ for $5 \mathrm{~min}$. The supernatants were tested for enzyme activities. Aliquots of lysates were subjected to thioredoxin reductase determination with the insulin reduction test [36]. Briefly, $12 \mu \mathrm{g}$ proteins of cell lysates were incubated for $40 \mathrm{~min}$ in a final volume of $50 \mu \mathrm{L}$ in $100 \mathrm{mM}$ HEPES buffer ( $\mathrm{pH}$ 7.6) and in the presence of $15 \mathrm{mM}$ EDTA, $1.5 \mathrm{mM}$ $\mathrm{NADPH}, 0.20 \mathrm{mM}$ insulin, and $100 \mu \mathrm{M}$ Trx from E. coli, at $37{ }^{\circ} \mathrm{C}$. The reaction was stopped by addition of $0.2 \mathrm{~mL}$ of $1 \mathrm{mM}$ DTNB in $0.2 \mathrm{M}$ Tris $\mathrm{HCl}$ buffer (pH 8.1) with $1 \mathrm{mM}$ EDTA and 7.2 M guanidine. Samples were estimated at $412 \mathrm{~nm}$ using a plate reader.

Glutathione reductase activity (80 $\mu \mathrm{g}$ of cell lysates) was measured in $0.2 \mathrm{M}$ Tris $\mathrm{HCl}$ buffer ( $\mathrm{pH} \mathrm{8.1)}$, $1 \mathrm{mM}$ EDTA, and $0.25 \mathrm{mM}$ NADPH. The assay was initiated by addition of $1 \mathrm{mM}$ GSSG and followed spectrophotometrically at $340 \mathrm{~nm}$.

\subsection{Redox Western blot analysis of Trx1, Trx2 and Prx3}


The redox state of Trx was detected using a modified Western blot analysis [37]. Briefly, Jurkat cells $\left(2 \times 10^{6}\right)$ were treated with $1(50 \mu \mathrm{M})$ and $2(15 \mu \mathrm{M})$ for $18 \mathrm{~h}$, washed with PBS and then lysed with $100 \mu \mathrm{L}$ of urea buffer (8 M urea dissolved in $100 \mathrm{mM}$ Tris $\mathrm{HCl}, \mathrm{pH} 8.3$ ) containing $1 \mathrm{mM}$ EDTA and $10 \mathrm{mM}$ IAM in order to alkylate free thiols. Incubation was carried out at $37{ }^{\circ} \mathrm{C}$ for $20 \mathrm{~min}$. After centrifugation, cell lysates were precipitated by ice-cold acetone-1 $\mathrm{N} \mathrm{HCl}$ (98:2). The obtained pellets were washed with ice-cold acetone $-1 \mathrm{~N} \mathrm{HCl}-\mathrm{H}_{2} \mathrm{O}$ (98:2:10), resuspended in $60 \mu \mathrm{L}$ of urea lysis buffer with $3.5 \mathrm{mM}$ DTT and incubated for $30 \mathrm{~min}$ at $37{ }^{\circ} \mathrm{C}$. Afterward, $3 \mu \mathrm{L}$ of $600 \mathrm{mM}$ IAA $(30 \mathrm{mM}$ final concentration) were added to the samples, followed by incubation for $30 \mathrm{~min}$ at $37{ }^{\circ} \mathrm{C}$. Protein concentration was determined by the Lowry assay [35]. Proteins were separated by urea-PAGE gel (7\% acrylamide/bis(acrylamide) in $7 \mathrm{M}$ urea) and blotted using Turbo System (Bio-Rad Laboratories, Hercules, CA, USA). Membranes were probed with the primary antibodies respectively for Trx1 (FL 105) and for Trx2 (H75) (Santa Cruz Biotechnology, Santa Cruz, CA, USA).

For the determination of Prx3 redox state, after incubation with $1(50 \mu \mathrm{M})$ and $2(15 \mu \mathrm{M})$ for $18 \mathrm{~h}$, Jurkat cells were collected, centrifuged at $500 \mathrm{~g}$ for $5 \mathrm{~min}$, washed with cold PBS and then treated with $1 \mathrm{~mL}$ of $10 \%$ trichloro-acetic acid. The samples were kept at $4{ }^{\circ} \mathrm{C}$ for $30 \mathrm{~min}$, and then centrifuged for $15 \mathrm{~min}$ at $15800 \mathrm{~g}$ at $4{ }^{\circ} \mathrm{C}$. Pellets washed with $1 \mathrm{~mL}$ of ice-cold acetone, were then centrifuged at $10000 \mathrm{~g}$ for $10 \mathrm{~min}$ at room temperature. The samples were dissolved in $670 \mathrm{mM}$ Tris $\mathrm{HCl}(\mathrm{pH} 7.5) 2 \%$ SDS medium containing $10 \mathrm{mM}$ AIS (4-acetamido-40-((iodoacetyl)amino)stilbene-2, 20-disulfonic acid) (Invitrogen). Derivatization lasted for $20 \mathrm{~min}$, at room temperature, followed by further $45 \mathrm{~min}$ at $37{ }^{\circ} \mathrm{C}$. Samples were loaded, without reducing agents, onto Bis-Tris Gel NUPAGE (12\%) and blotted. To assess the redox state of Prx3, a monoclonal antibody LF-MA0044 (Histoline) was used.

\subsection{ROS formation}

The generation of reactive oxygen species (ROS) was assessed by the fluorogenic probe CMDCFH2-DA (Molecular Probes, Invitrogen). Jurkat cells $\left(4 \times 10^{4}\right.$ per well) were seeded in PBS/10 mM glucose. After $1 \mathrm{~h}$ cells were loaded with $1 \mu \mathrm{M}$ CM-DCFH2-DA and with increasing concentrations of the compounds. Fluorescence increase, $485 \mathrm{~nm}(\mathrm{Ex})$ and $527 \mathrm{~nm}(\mathrm{Em})$, was followed for $2 \mathrm{~h}$ using a plate reader (Tecan Infinite® M200 PRO).

\subsection{Flow cytometry analysis}

Drug-influenced cell mitochondrial membrane potential was analyzed by flow cytometry. Jurkat cells $\left(1 \times 10^{6}\right.$ cells $)$ were treated for $18 \mathrm{~h}$ in presence of $\mathbf{1}(15$ or $50 \mu \mathrm{M})$ and $2(10$ or $15 \mu \mathrm{M})$. 
Cells were then collected, resuspended in PBS/10 mM glucose $\left(2.5 \times 10^{5} / \mathrm{mL}\right)$ and loaded with $25 \mathrm{nM}$ TMRM at $37^{\circ} \mathrm{C}$ in the dark, for $15 \mathrm{~min}$. Induced changes of membrane potential were estimated with a FACSCanto $^{\text {TM }}$ II flow cytometer (Becton-Dickinson, CA, USA) using an argon laser at $585 \mathrm{~nm}$.

\subsection{Quantitative enzymatic oxidation of 1 by the $\mathrm{HRP} / \mathrm{H}_{2} \mathrm{O}_{2}$ system}

Enzymatic oxidation was performed on $1(100 \mu \mathrm{M}, 976 \mu \mathrm{g})$ in $\mathrm{H}_{2} \mathrm{O} / \mathrm{DMSO}$ 9:1 (18 $\left.\mathrm{mL}\right)$. Solutions of $\mathrm{HRP}\left(110 \mathrm{nM}\right.$ final) and $\mathrm{H}_{2} \mathrm{O}_{2}(0.5 \mathrm{mM}$ final) were pre-incubated for 5 min then added to the aqueous solution of $\mathbf{1}$. The colorless solution progresseively turned to yellow. The kinetics of the reaction was followed by the appearance of a peak at $329 \mathrm{~nm}$ in the UV-VIS and the reaction was complete in $20 \mathrm{~min}$. Then, 2 equivalents of $\mathrm{NaBPh}_{4}$ were added, leading to the formation of a yellow precipitate. This precipitate was recovered by centrifugation at $11500 \mathrm{~g}$ for $10 \mathrm{~min}$, and washed twice with a small volume of cold water $(100 \mu \mathrm{L})$. Finally, the precipitate was dissolved in methanol (100 $\mu \mathrm{L})$. This solution was analyzed by UV-VIS and mass spectrometry.

\section{RESULTS}

\subsection{Synthesis of the osmocifens 1,2 and of their corresponding quinone methides (QMs)}

The two osmium-based tamoxifen derivatives, $\mathbf{1}$ and $\mathbf{2}$ were prepared following the protocol recently published by some of us [26]. Their corresponding quinone methides 1-QM and 2-QM were synthesized by chemical oxidation with freshly prepared $\mathrm{Ag}_{2} \mathrm{O}$ at room temperature and obtained with high yield (89 and $90 \%$ respectively; see experimental section).
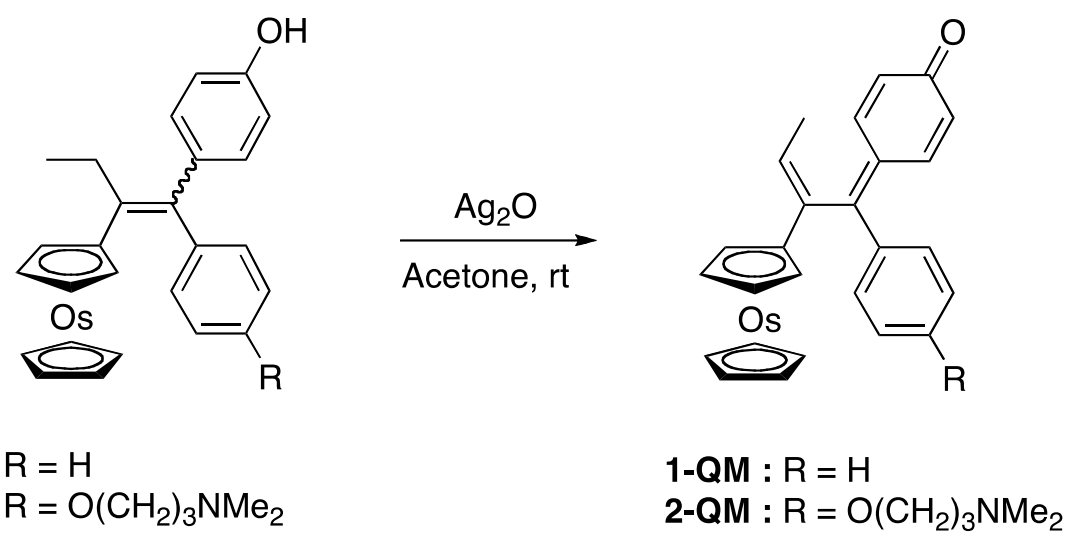

$$
\begin{aligned}
& 1: \mathrm{R}=\mathrm{H} \\
& 2: \mathrm{R}=\mathrm{O}\left(\mathrm{CH}_{2}\right)_{3} \mathrm{NMe}_{2}
\end{aligned}
$$

Scheme 1 : Synthesis of quinone methides (QMs) 
The stability of $\mathbf{1}$ and $\mathbf{2}$ was studied by UV-VIS spectrometry. They are both stable for at least 3 days in aqueous medium ( $25 \mu \mathrm{M}$ in Tris $\mathrm{HCl}(\mathrm{pH} 8.1), 1 \mathrm{mM}$ EDTA, 2.5\% DMSO) (decrease of the characteristic absorbance of 1 and 2 at $300 \mathrm{~nm}$ less than 20\%). (Fig. S1)

\subsection{Enzymatic oxidation of 1 and 2 by the $\mathrm{HRP} / \mathrm{H}_{2} \mathrm{O}_{2}$ system}

In the presence of the enzymatic oxidizing system $\mathrm{HRP} / \mathrm{H}_{2} \mathrm{O}_{2}$, complexes $\mathbf{1}$ and 2, undergo oxidation with formation of new derivatives called $1 *$ and $2 *$. The rate of formation of $1 *$ and $2 *$, can be followed by UV-VIS spectrometry (Fig. 1 and Fig. S2). Following addition of the $\mathrm{HRP}_{2} \mathrm{H}_{2} \mathrm{O}_{2}$ mixture, we observed the rapid decrease of the shoulder characteristic of $\mathbf{1}$ and $\mathbf{2}$, around $300 \mathrm{~nm}$ together with the appearance of a peak at $323 \mathrm{~nm}$ that characterizes $1^{*}$ or $2^{*}$. The formation of these species is rapid and slightly faster for $2^{*}$ than for $\mathbf{1}^{*}$. Mathematical treatment of the UV-VIS data according the first order law gave $t_{1 / 2}=6.7$ and 4.0 min, respectively (Fig. S3, Table S1). As shown on Fig. 1, UV-VIS spectra of $\mathbf{1}^{*}$ and $\mathbf{2}^{*}$ are clearly different from those of their corresponding quinone methides 1-QM and 2-QM which show peaks at $365 \mathrm{~nm}$ and $417 \mathrm{~nm}$, respectively. Interestingly, while slow evolution of the UV-visible spectrum of $1 *$ and $2 *$ was observed with time they did not convert in the quinone methides even after $10 \mathrm{~h}$ (Fig. S4). It should also be noticed that the rate of formation of $2 *$ is significantly higher than that of $\mathbf{2 - Q M}$ obtained by chemical oxidation (Table $\mathrm{S} 1)\left(\mathrm{t}_{1 / 2}=4\right.$ min for $2 *$ versus 24 min for 2-QM). 

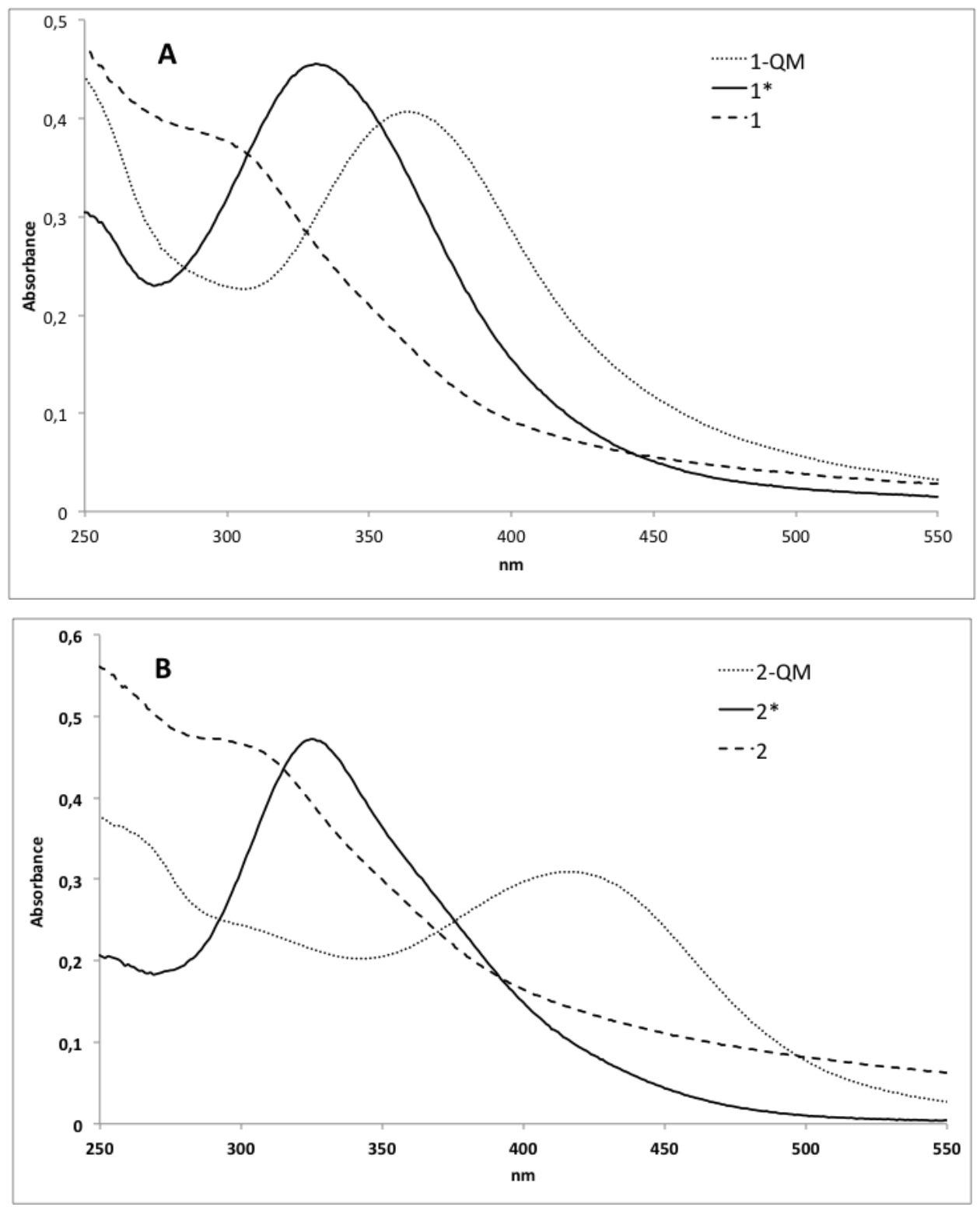

Fig. 1. Superimposition of the UV-VIS spectra of $25 \mu M$ of 1 (A) or 2 (B), their quinone methides (1$\mathbf{Q M}$ and 2-QM) and $\mathbf{1}^{*}, 2^{*}$ the compounds obtained by enzymatic oxidation of $\mathbf{1}$ and $\mathbf{2}$ of with the $\mathrm{HRP} / \mathrm{H}_{2} \mathrm{O}_{2}$ system after 20 min. Spectra were recorded with $25 \mu \mathrm{M}$ compounds in $0.2 \mathrm{M}$ Tris $\mathrm{HCl}$ buffer (pH 8.1), 1 mM EDTA and 2.5\% DMSO. 1 and 2 are characterized by a shoulder around 300 $\mathrm{nm}, 1 *$ and $2 *$ by a peak at $323 \mathrm{~nm}, \mathbf{1 - Q M}$ and 2-QM by peaks at 365 and $417 \mathrm{~nm}$, respectively.

\subsection{Inhibitory effect on isolated thioredoxin reductase of osmocifens 1 and 2 , their oxidized derivatives $1 *$ and $2 *$ and the quinone methides 1-QM and 2-QM}

The inhibitory effect of $\mathbf{1}$ and $\mathbf{2}$ on thioredoxin reductase 1 (TrxR1) activity before and after enzymatic oxidation with $\mathrm{HRP} / \mathrm{H}_{2} \mathrm{O}_{2}$ was first evaluated. As shown on Fig. 1A, 1 and 2 are scarcely effective on TrxR1 up to a concentration of $20 \mu \mathrm{M}$, while they both acquire remarkable inhibitory 
properties after oxidation with the $\mathrm{HRP} / \mathrm{H}_{2} \mathrm{O}_{2}$ system. Oxidized complex $2\left(2^{*}\right)$ is a little more active than oxidized complex $\mathbf{1}\left(\mathbf{1}^{*}\right)\left(\mathrm{IC}_{50}=1.2 \mu \mathrm{M}\right.$ and 2.4, respectively). Quinone methides, 1-QM and 2QM, are also effective inhibitors of the enzyme although to a lower extent (Fig. 1B; $\mathrm{IC}_{50}=5.4$ and 3.6 $\mu \mathrm{M}$ respectively). In addition, compounds 1,2 and $1 *$ and $2 *$ were tested on mitochondrial thioredoxin reductase activity in vitro (Fig. S7) and only the transformed compounds treated with $\mathrm{HRP}$ and $\mathrm{H}_{2} \mathrm{O}_{2}$ show a significant inhibition of TrxR2.
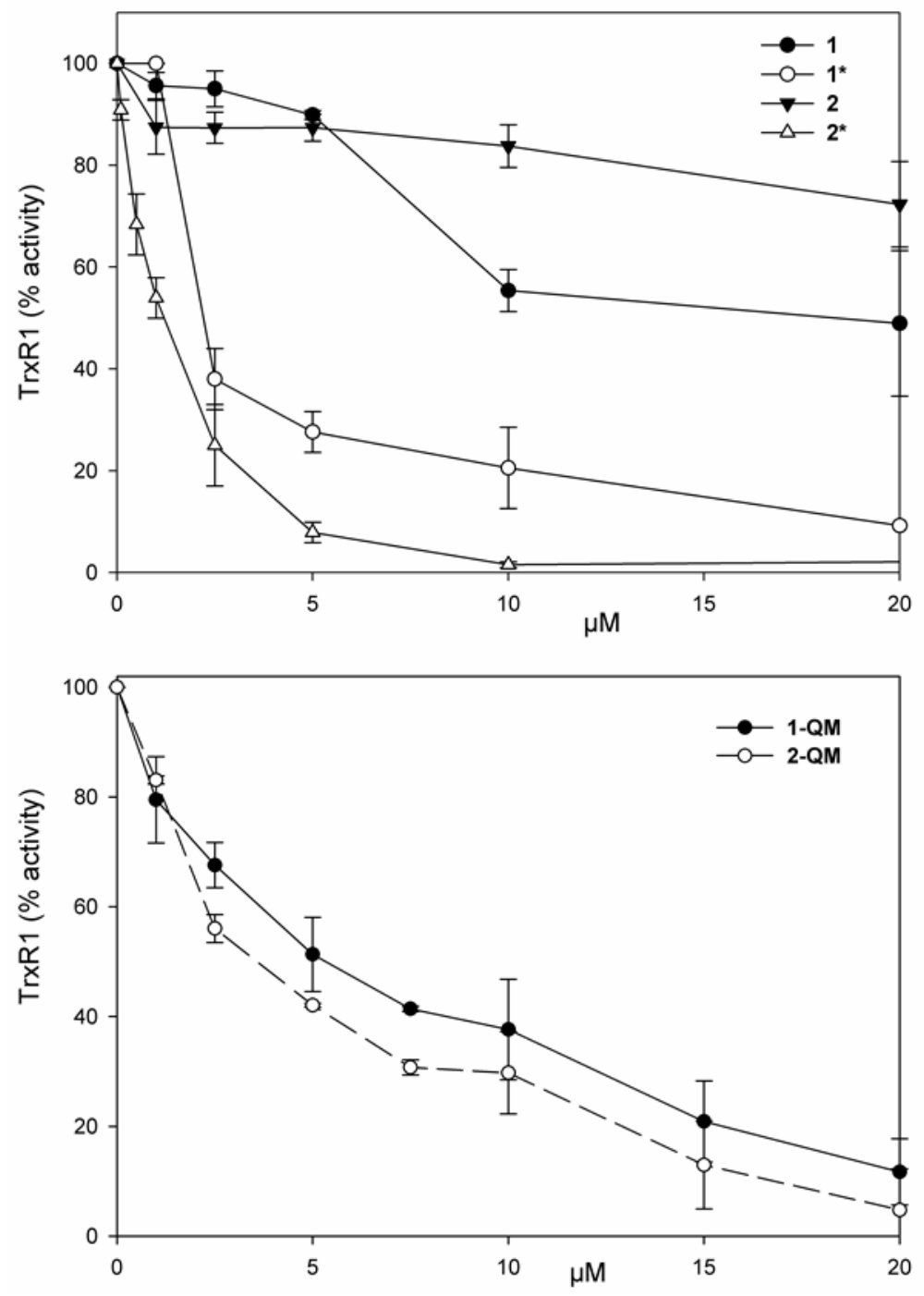

Fig. 2. Thioredoxin reductase 1 (TrxR1) inhibition with osmocifen compounds

1, 2 and the compounds obtained after pre-treatment for 15 min of 1 and 2 with $0.1 \mathrm{mM} \mathrm{H}_{2} \mathrm{O}_{2}$ and 22 $n M H R P(1 *, 2 *)$, were incubated in $0.2 \mathrm{M}$ Tris HCl buffer ( $\mathrm{pH}$ 8.1), $1 \mathrm{mM}$ EDTA with $0.25 \mathrm{mM}$ NADPH and $60 \mathrm{nM}$ TrxR1. After $5 \mathrm{~min}$, TrxR1 activity was estimated as described in Materials and methods. Under the same experimental conditions the $\mathrm{HRP} / \mathrm{H}_{2} \mathrm{O}_{2}$ mixture is ineffective on TrxRI activity in the absence of osmocifen compounds (A). Thioredoxin reductase activity was estimated in the same experimental conditions after a 5 min treatment with $1-Q M$ or $2-Q M(B)$. 


\subsection{Antiproliferative effect and ROS production of 1 and 2 in Jurkat cells}

The antiproliferative effect of $\mathbf{1}$ and $\mathbf{2}$ was studied on Jurkat cells incubated for $24 \mathrm{~h}$. As shown in Fig. $3 \mathrm{~A}$, complex 2 exhibits a strong antiproliferative effect $\left(\mathrm{IC}_{50}=7.4 \mu \mathrm{M}\right)$ while $\mathbf{1}$ is significantly less cytotoxic $\left(\mathrm{IC}_{50}=42 \mu \mathrm{M}\right)$. ROS production was then estimated in Jurkat cells after $2 \mathrm{~h}$ incubation (Fig. $3 \mathrm{~B}$ ) and, similarly to the antiproliferative effect compound, $\mathbf{2}$ is more effective than $\mathbf{1 .}$

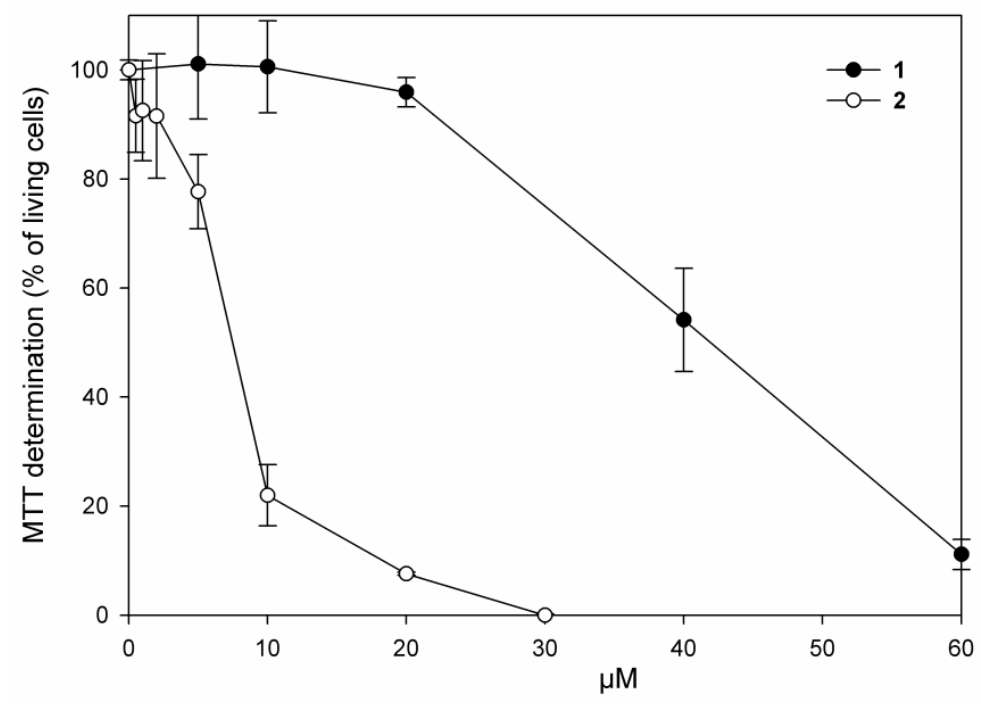

A

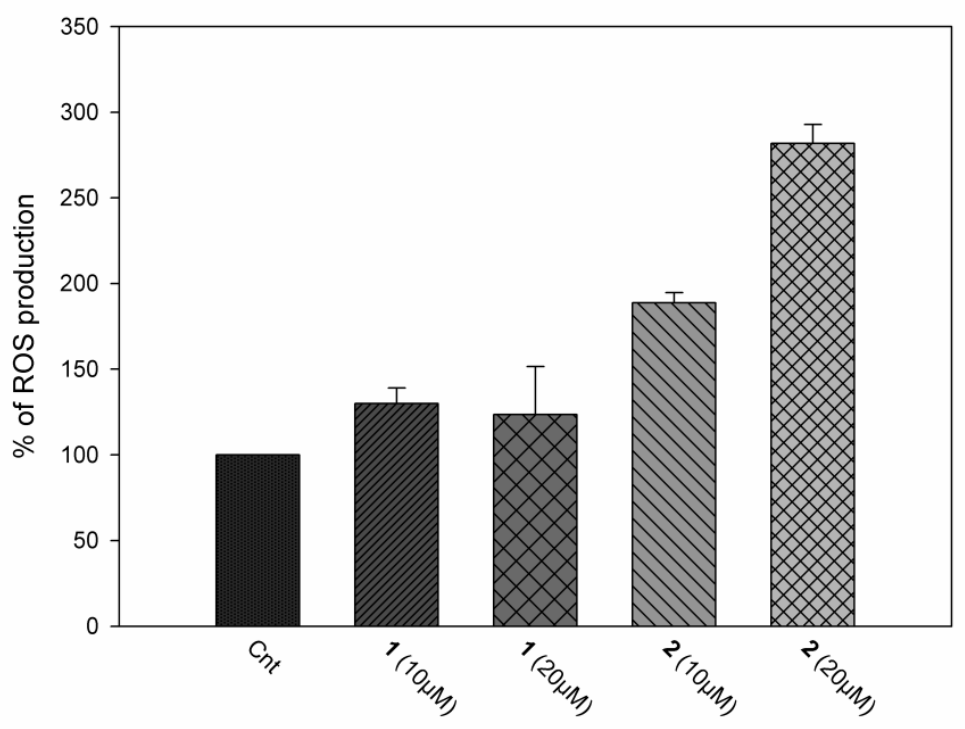

Fig. 3. Estimation of Jurkat cell viability $(A)$ and ROS production $(B)$ after treatment with compound 1 or 2. Cell viability was measured with the MTT test in $8 \times 10^{4}$ cells treated for $24 \mathrm{~h}$ with the osmocifens as indicated in Materials and methods. For ROS production $4 \times 10^{4}$ cells were incubated in PBS/10 mM glucose medium in the presence of $1 \mu M C M-D C F H 2-D A$ and of the osmocifens at the indicated concentrations. Reaction was followed as fluorescence increase and the reported values were obtained after 120 min of incubation. 


\subsection{Cellular uptake of 1 and 2}

Quantification of Os in whole cells incubated for $24 \mathrm{~h}$ in the presence of $\mathbf{1}(50 \mu \mathrm{M})$ or $\mathbf{2}(15$ $\mu \mathrm{M}$ ) was performed by ICP-OES (Table S2). The amount of Os found in one cell was 3.9 fmol for 1 and 4.2 fmol for $\mathbf{2}$. Interestingly the amount of osmium is higher in cells incubated with $15 \mu \mathrm{M}$ of $\mathbf{2}$, the most cytotoxic complex, than in cells incubated with $50 \mu \mathrm{M}$ of $\mathbf{1}$ the less cytotoxic molecule.

\subsection{Effect of 1 and 2 on the activity of thioredoxin reductase (TrxR) and glutathione reductase} (GR) in Jurkat cells

Similarly to what observed in vitro with the $\mathrm{H}_{2} \mathrm{O}_{2} / \mathrm{HRP}$ system, compounds $\mathbf{1}$ and $\mathbf{2}$ can be oxidatively metabolized in cultured cells into species able to interact with the various enzymatic targets. On this basis, we have evaluated the total thioredoxin reductase and glutathione reductase activities in Jurkat cell lysates incubated with compound $\mathbf{1}$ or $\mathbf{2}$. Both GR and TrxR are pyridine disulfide oxidoreductases, however GR lacks the easily accessible C-terminal -Cys-SeCys- motif which characterises TrxR and is the target of a great deal of inhibitors.
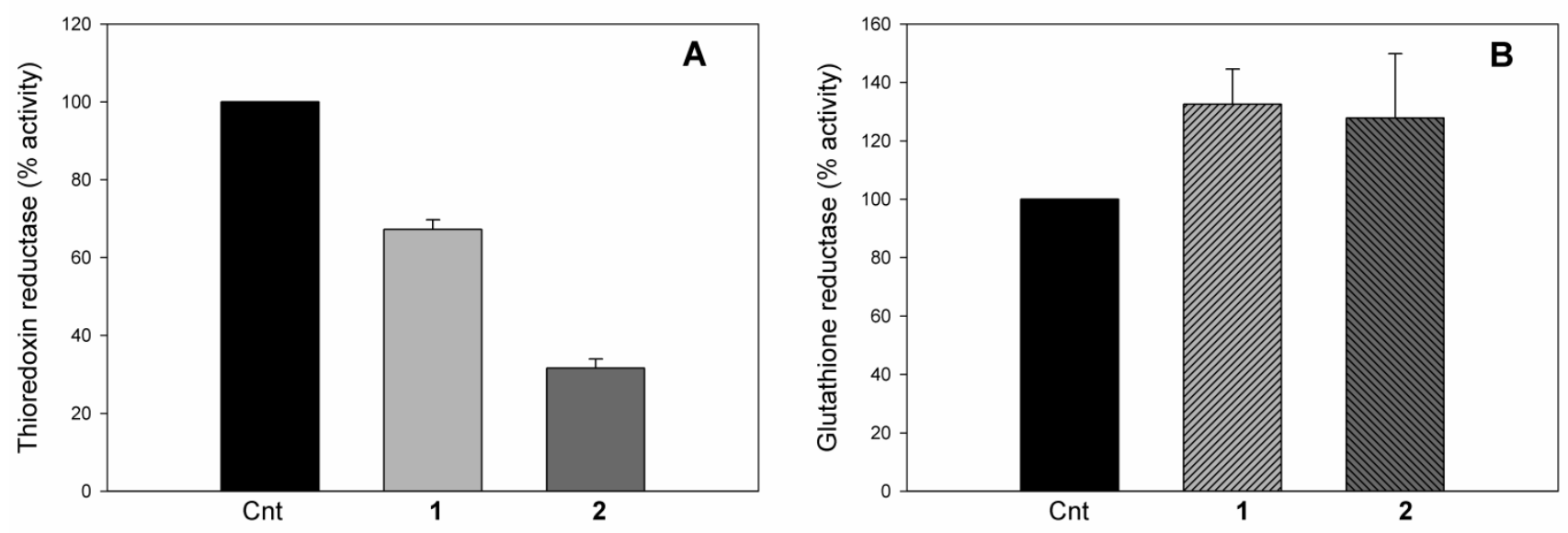

Fig. 4. $\operatorname{Tr} x R(A)$ and $G R(B)$ activities in Jurkat cell lysates.

Jurkat cells $\left(2 \times 10^{6}\right)$ were incubated for $18 \mathrm{~h}$ with $1(50 \mu \mathrm{M})$ or $2(15 \mu \mathrm{M})$ and then lysed. Activities of the two redox enzymes were estimated as reported in Materials and methods.

As shown in Fig. 4 A both 1 and 2 inhibit total TrxR activity. However, 2 is far more effective than 1 as, at $15 \mu \mathrm{M}$, it inhibits the enzyme activity by almost $70 \%$, while $\mathbf{1}$, even at a higher concentration $(50 \mu \mathrm{M})$, is effective by only $30 \%$. The activity of GR is not inhibited by $\mathbf{1}$ or $\mathbf{2}$, but 
instead is slightly stimulated (Fig. 4 B). Interestingly, 1 and 2 at the reported concentrations (50 and 15 $\mu \mathrm{M}$, respectively) do not inhibit TrxR activity in the non-tumor cell line HEK293 as shown in Fig. S8.

\subsection{Effect of compounds 1 and 2 on the oxidized state of thioredoxin (Trx1 and Trx2) and peroxiredoxin 3 (Prx3) in Jurkat cells}

Thioredoxin reductase belongs to the thioredoxin system, which is a relevant metabolic pathway for the maintenance of cellular thiols in a reduced state. The major substrate of thioredoxin reductase, thioredoxin, in turn delivers electrons to peroxiredoxin which removes hydrogen peroxide and participates in signaling processes. We therefore examined the thiol redox state of both cytosolic and mitochondrial thioredoxins (Trx1 and $\operatorname{Trx} 2)$ and the redox conditions of mitochondrial peroxiredoxin (Prx3). For estimation of Trx1/2 a modified redox Western blot, specific for thiol oxidation states, was used (see Materials and methods). In this blot the upper band indicates the fully reduced enzyme while the lowest indicates the completely oxidized form. The intermediate bands indicate the partial formation of disulfides, mixed disulfides with protein thiols or glutathione, or nitrosylated residues. The number of bands is related to the amount of thiols originally present in each thioredoxin isoform. As shown in Fig. 5 and consistently with the results of Fig. 4 A, complex 2 appears extremely effective in stimulating the oxidation of both Trx 1 and Trx2. In addition, Prx3, appears to be completely oxidized (dimeric form) after treatment of cells with $\mathbf{2}$. Complex $\mathbf{1}$, even at higher concentrations is far less effective than $\mathbf{2}$ as, although inducing some oxidation of Trx 1 and Trx2, it appears unable to stimulate the oxidation of Prx3. 

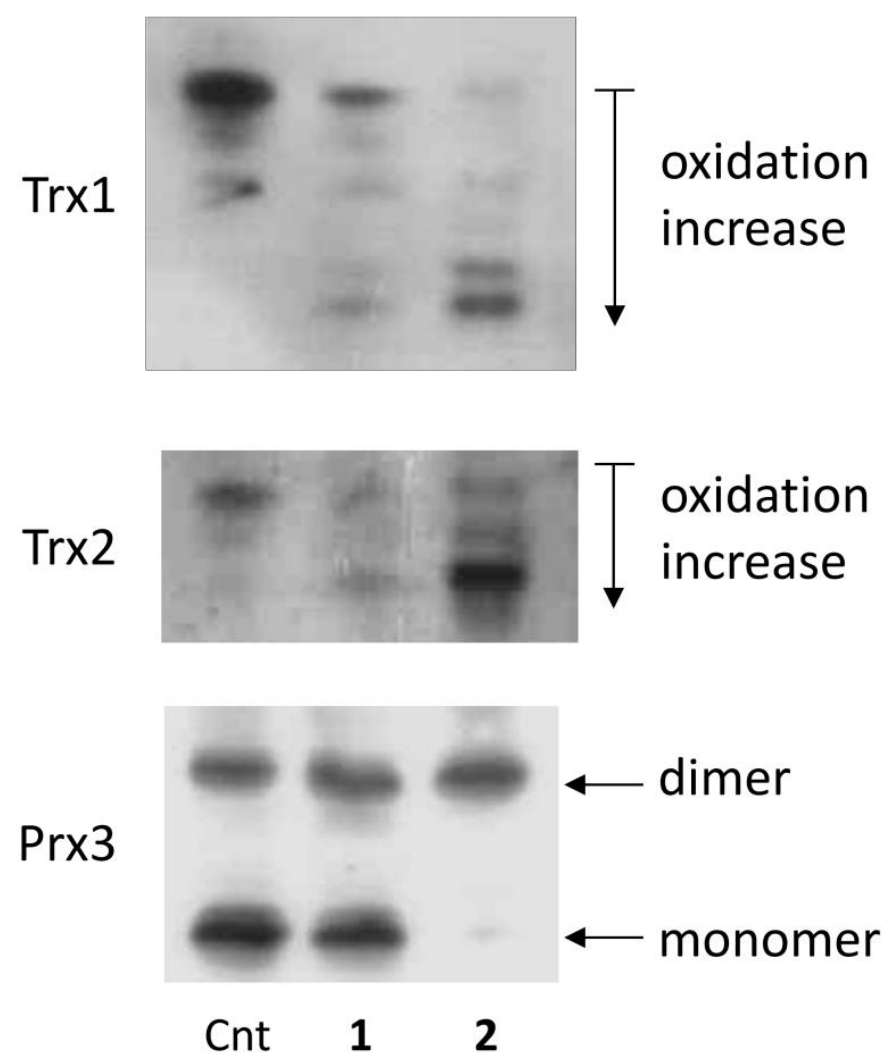

Fig. 5. Jurkat cells $\left(2 \times 10^{6}\right)$, treated for $18 \mathrm{~h}$ with 1 and $\mathbf{2}$, were derivatized with $10 \mathrm{mM}$ IAM to titrate free SH groups. Then, after treatment with DTT (3.5 mM), an excess of IAA (30 mM) was added, giving rise to derivatized groups corresponding to the oxidized residues. The determination of redox state of Trxl, Trx2 was performed with urea-PAGE in non reducing conditions and the bands, detected with WB analysis, correspond to the different oxidation states of Trx1 or Trx2. For the estimation of the redox state of Prx3, cell lysates were derivatized with $10 \mathrm{mM}$ AIS to alkylate free thiols and subjected to SDS-PAGE in non reducing conditions as described in Materials and methods. Dimer corresponds to disulfide-linked oxidised form while monomer refers to the reduced form.

\subsection{Effect of 1 and 2 on mitochondrial membrane potential (MMP)}

In order to confirm that mitochondria are a key target of the antiproliferative activity observed with $\mathbf{2}$, the effects of $\mathbf{1}$ and $\mathbf{2}$ on the mitochondrial membrane potential of Jurkat cells were studied. As seen in Fig. 6, complex 2, even at the lower concentration $(10 \mu \mathrm{M})$, is markedly more effective than 1 in decreasing mitochondrial membrane potential (MMP) as shown by the decline of fluorescence intensity (Fig. 6 and Table 1). 

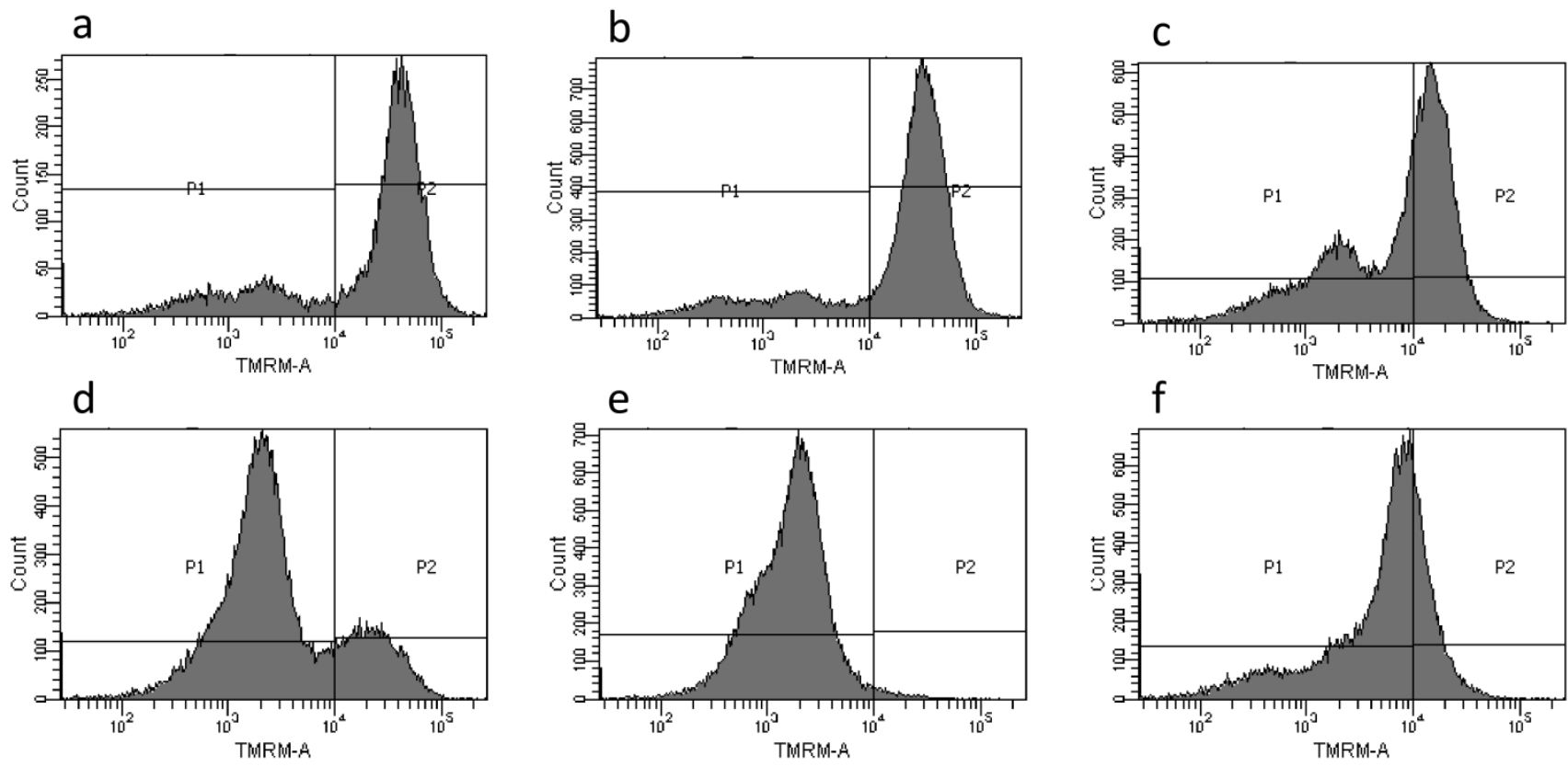

Fig. 6. Mitochondrial membrane potential (MMP) of Jurkat cells in the presence of 1 and 2. Cells were treated for $18 \mathrm{~h}$ with 1 (15 and $50 \mu \mathrm{M})$ or 2 (10 and 15 $\mathrm{MM})$ and MMP was measured using TMRM and detected by flow cytometry analysis. P1 corresponds to cell population with low membrane potential, while $P 2$ is related to cell population with high membrane potential. a, control; $b, 15 \mu M 1$; $c, 50 \mu M$ 1; $d, 10 \mu M 2 ; e, 15 \mu M 2 ; f, 1 \mu M C C C P$ used a positive control.

Table 1: Percentage of cells with high and low mitochondrial membrane potential (MMP) after treatment with 1 or 2 . Jurkat cells were treated with $50 \mu \mathrm{M} 1$ or $15 \mu \mathrm{M} 2$ in the conditions described above. Data are reported as mean \pm SD of five experiments.

\begin{tabular}{ccc}
\hline & high MMP $(\%)$ & low $\operatorname{MMP}(\%)$ \\
\hline Control & $82 \pm 5$ & $18 \pm 5$ \\
$\mathbf{1}$ & $61 \pm 11$ & $39 \pm 11$ \\
$\mathbf{2}$ & $3 \pm 0$ & $98 \pm 1$ \\
\hline
\end{tabular}

\section{DISCUSSION}

The results of the different tests performed with osmocifens $\mathbf{1}$ and $\mathbf{2}$ in vitro on purified thioredoxin reductase and in cellulo on Jurkat cells are summarized in Table 2. 
Table 2 : Summary of the biological studies performed with $\mathbf{1}$ and $\mathbf{2}$ in vitro or on Jurkat cells.

\begin{tabular}{|c|c|c|}
\hline & 1 & 2 \\
\hline & \multicolumn{2}{|c|}{ Inhibition of cytosolic $\operatorname{TrxR}\left(\mathrm{IC}_{50}\right.$ in $\left.\mu \mathrm{M}\right)$} \\
\hline Complex alone & $\geq 20$ & $>20$ \\
\hline Complex pre-treated with $\mathrm{HRP} / \mathrm{H}_{2} \mathrm{O}_{2}$ & $2.4 \pm 0.3$ & $1.2 \pm 0.1$ \\
\hline \multirow[t]{2}{*}{ Quinone methide } & $5.4 \pm 0.7$ & $3.6 \pm 0.1$ \\
\hline & \multicolumn{2}{|c|}{ Tests on Jurkat cells } \\
\hline $\mathrm{IC}_{50}$ values of MTT Test $(\mu \mathrm{M})$ & $42 \pm 4$ & $7.4 \pm 0.8$ \\
\hline \multirow[t]{2}{*}{ ROS production $(20 \mu \mathrm{M}$ of $\mathbf{1 - 2})$} & + & +++ \\
\hline & $\underline{\text { Effect of } 50 \mu \mathrm{M} \text { of } 1}$ & Effect of $15 \mu M$ of 2 \\
\hline$\%$ of TrxR inhibition in cell lysates & $32.8 \pm 1.2$ & $68.4 \pm 1.2$ \\
\hline Trx 1 redox state & $40 \%$ oxidised & $95 \%$ oxidised \\
\hline Trx 2 redox state & $50 \%$ oxidised & $82 \%$ oxidised \\
\hline Prx3 redox state & $\begin{array}{l}\text { Mainly reduced (60\% } \\
\text { monomer form) }\end{array}$ & $\begin{array}{l}\text { Completely oxidised (98\% } \\
\text { dimer form) }\end{array}$ \\
\hline GR activity in cell lysates & slight increase & slight increase \\
\hline$\%$ of cells with high MMP & $61 \pm 11$ & $3 \pm 0.1$ \\
\hline
\end{tabular}

The results of the in vitro study on the inhibition of purified TrxR clearly show that complexes $\mathbf{1}$ and 2 have no inhibitory effect until after their enzymatic oxidation by the $\mathrm{H}_{2} \mathrm{O}_{2} / \mathrm{HRP}$ system and that the inhibition observed is very similar for the two complexes $\left(\mathrm{IC}_{50}=2.4\right.$ and $\left.1.2 \mu \mathrm{M}\right)$. This inhibition is stronger than that found after incubation in the presence of the quinone methides 1-QM and 2-QM $\left(\mathrm{IC}_{50}=5.4\right.$ and $\left.3.6 \mu \mathrm{M}\right)$. In addition, the UV-VIS spectra of $1^{*}$ and $2 *$, the species obtained by treatment of 1 and 2 with $\mathrm{HRP} / \mathrm{H}_{2} \mathrm{O}_{2}$, do not correspond to those of their quinone methides (Fig. 2) as it was the case in the ferrocifen series [32]. This result should also be viewed from the perspective of the recent observation that the electrochemical oxidation of $\mathbf{1}$ corresponds, in the presence of a base, to a 2electron transfer but does not lead to the corresponding QM [26]. Looking again at the oxidation pathway previously established for the ferrocifens, the hypothesis can be made that in the case of the osmocifens, the corresponding quinone methide cation $\left(\mathrm{QM}^{+}\right)$, obtained after a first oxidation of the complex, the removal of the phenolic proton and a second oxidation, could be the reactive species responsible for the inhibition of $\operatorname{TrxR}$ (Scheme 2). This corresponds to a cessation of the reaction sequence at an earlier step than that of neutral quinone methide. This hypothesis is in agreement with 
the stabilization sequence of carbocations and radicals in the metallocene triad, in the order $\mathrm{Fe}<\mathrm{Ru}<$ Os, with osmium being the most stabilized [38, 39].

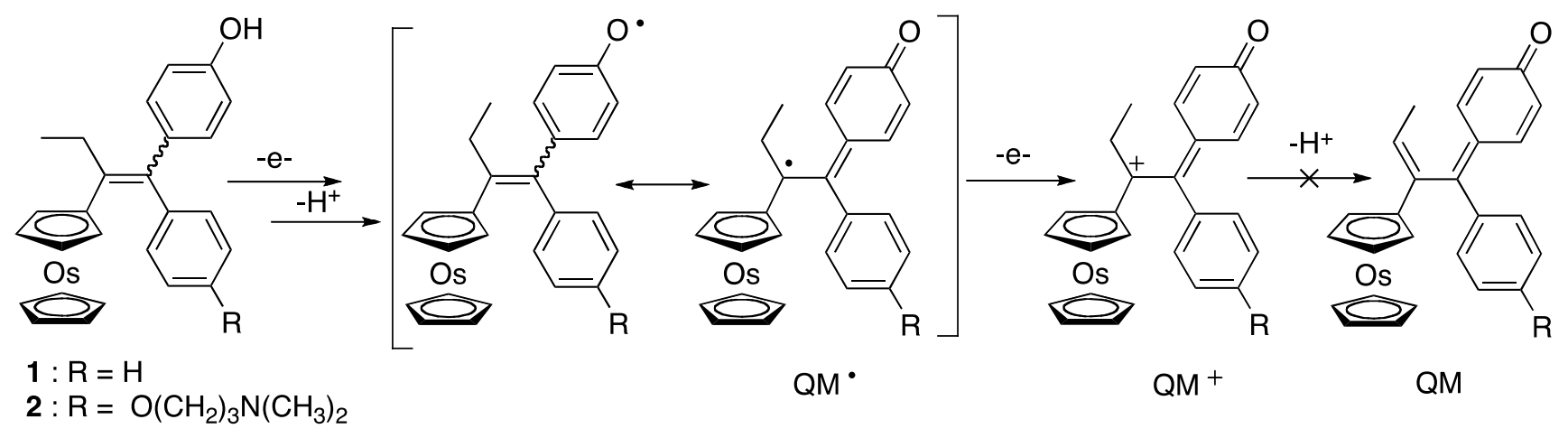

Scheme 2: Hypothesis for the oxidation sequence of 1 and $\mathbf{2}$ (adapted from ref [4]).

If this hypothesis is correct, $\mathbf{1}^{*}$ and $\mathbf{2}^{*}$, i.e. the species generated by enzymatic oxidation by the $\mathrm{HRP} / \mathrm{H}_{2} \mathrm{O}_{2}$ system of $\mathbf{1}$ and $\mathbf{2}$, should have a reasonable chance to correspond to these quinone methide cations. In order to check this assumption we tried to precipitate $1^{*}$ (which is more stable than $2^{*}$ cf. Fig. S3 and Fig. S4) by addition of $\mathrm{BPh}_{4}{ }^{-}$, an anion previously used to get single crystals of osmocenyl carbenium ion [39]. This experiment was performed as follows: 1* was generated by incubation of 1 in the presence of a mixture of $\mathrm{HRP} / \mathrm{H}_{2} \mathrm{O}_{2}$ for $20 \mathrm{~min}$. Then addition of 2 equivalents of $\mathrm{NaBPh}_{4}$ afforded a yellow precipitate that was recovered by centrifugation, washed, then dissolved in methanol leading to a bright yellow solution (see Material and methods). The UV-VIS spectrum of this solution is similar to that obtained for $1 *$ (Fig. S5). Electrospray mass spectroscopic analysis of the solution gave a main molecular ion at $\mathrm{m} / \mathrm{z}=543.5 \mathrm{amu}$ in the positive mode and an isotope pattern matching that of $\mathbf{1 - Q \mathbf { M } ^ { + }}$. In the negative mode, the molecular peak was at $319 \mathrm{amu}$, corresponding to the $\mathrm{BPh}_{4}{ }^{-}$counterion. (Fig. S6). Thus this hypothesis of a reactive quinone methide carbocation in the osmocifen series appears plausible.

The series of experiments performed in cellulo on Jurkat cells shows that in the majority of trials performed, complexes $\mathbf{1}$ and $\mathbf{2}$ behave in different ways. This is particularly true for their cytotoxicity. While the phenolic complex 1 has low toxicity $\left(\mathrm{IC}_{50}=42 \mu \mathrm{M}\right)$, the tamoxifen-like complex 2 exhibits a high level of cytotoxicity $\left(\mathrm{IC}_{50}=7.4 \mu \mathrm{M}\right)$. Interestingly, this difference in cytotoxicity can be compared with the efficiency of inactivation of TrxR by the complexes in Jurkat cells. In fact, while 2 induces very strong inhibition of $\operatorname{TrxR}(70 \%$ inhibition for $15 \mu \mathrm{M}$ incubation), that produced by $\mathbf{1}$ is much more modest (30\% inhibition at $50 \mu \mathrm{M}$ incubation). This result explains the 
redox state of Trx1, Trx2 and of Prx3 which are markedly oxidized upon treatment with 2. This is likely a consequence of the inhibition of TrxR by oxidation products of $\mathbf{2}$ hampering the electron flow delivery to Trx and hence to Prx3. Consequently, the shift of Trx1/2 and Prx3 toward a more oxidized condition, associated to an increase of ROS, may contribute to the decrease of mitochondrial membrane potential (MMP) observed for cells incubated in the presence of 2.

A large difference in toxicity between these two complexes has also recently been observed on MDA-MB-231 cells ( $\mathrm{IC}_{50}=34 \mu \mathrm{M}$ for 1 and $2.7 \mu \mathrm{M}$ for 2 ) [26]. In the citation given, the parameters studied to explain these differences in reactivity (lipophilicity, solubility and speed of formation of quinone methides, difference in the acidity of the phenolic protons), did not permit a satisfactory explanation of the difference in their cytotoxicity. Here, TrxR appears as a privileged target to explain the high cytotoxicity of $\mathbf{2}$ as well as the difference in cytotoxicity between $\mathbf{1}$ and $\mathbf{2}$.

The fact that complex 2 induces strong inhibition of TrxR indicates that the latter undergoes oxidation in cells due to the presence of oxidizing systems such as cytochromes P450 (CYP 450). We have also recently shown that the oxidative metabolism of the ferrocifens by CYP 450 led to the formation of three principal metabolites, namely quinone methide, cyclic indene and allylic alcohol, which in some cases possess high cytotoxicity [28]. With the osmocifens we do not observe formation of quinone methides, but formation of other active metabolites could be envisaged, such as the quinone methide carbocation mentioned above. As for the difference in behavior between $\mathbf{1}$ and $\mathbf{2}$ observed in Jurkat cells, it is clearly associated with the presence of the $\mathrm{O}\left(\mathrm{CH}_{2}\right)_{3} \mathrm{~N}\left(\mathrm{CH}_{3}\right)_{2}$ side chain. This may be related to a stabilization associated with the oxygen-donating mesomeric effect. A difference in the inhibition of TrxR activity has also been found in the ferrocifen series after incubation with Jurkat cells [32]. As here, the inhibition is more marked for the tamoxifen-like complex than for the phenolic, but it is not correlated with the antiproliferative effect of the complexes [32].

As far as production of ROS by Jurkat cells is concerned, complex 2 induces greater production than 1, which was also observed in the ferrocifen series [40]. This ROS production would be the source of the increase in activity of glutathione reductase. This absence of inhibition of GR also shows that the osmocifens $\mathbf{1}$ and $\mathbf{2}$ can only react with nucleophilic selenols and not with thiols, similarly to the ferrocifens.

In conclusion, the cytotoxicity of osmocifen compounds was dependent on its intracellular conversion to species able to interact with specific targets of cancer cells. TrxR appears as a pivotal site of inhibition that stimulates a series of events leading to the death of the cancer cells. 


\section{Abbreviations}

AIS, 4-acetamido-4'-((iodoacetyl)amino)stilbene-2,2'-disulfonic acid; CCCP, carbonyl cyanide-mchlorophenylhydrazone; DTNB, 5,5'-dithiobis(2-nitrobenzoic acid); GR, glutathione reductase; HRP, horseradish peroxidase; $\mathrm{CM}_{-} \mathrm{DCFH}_{2}$-DA, 5-(and-6)-chloromethyl-2',7'-dichlorodihydrofluorescein diacetate acetyl ester; IAA, iodoacetic acid; IAM, iodoacetamide; Prx, peroxiredoxin; ROS, reactive oxygen species; TAM, tamoxifen; TMRM, tetramethylrhodamine methyl ester; Trx, thioredoxin; TrxR, thioredoxin reductase; PMSF, phenylmethylsulfonyl fluoride.

\section{Acknowledgements}

The authors acknowledge PRIN 20107Z8XBW granted by Ministero dell'Istruzione, Università e Ricerca (MIUR) Italy, CPDA130272 granted by University of Padova (Italy) and also COST Actions CM1105 and CM1106 for financial support and for fostering fruitful discussions among authors. H. Z. S. L. gratefully acknowledges research Scholarship under the NTU-ParisTech joint PhD Programme. Dr. Céline Fosse is gratefully acknowledged for the in-depth mass spectroscopic analysis of the carbocation. The authors thank Barbara McGlinchey for her valuable help. 


\section{References}

[1] G. Jaouen, N. Metzler-Nolte, Medicinal Organometalllic Chemistry, in: G. Jaouen, N. MetzlerNolte (Eds.) Topics in Organometallic Chemistry, Springer, Heidelberg, 2010.

[2] N.P.E. Barry, P.J. Sadler, Exploration of the medical periodic table: towards new targets, Chem. Commun., 49 (2013) 5106-5131.

[3] M. Dörr, E. Meggers, Metal complexes as structural templates for targeting proteins, Curr. Op. Chem. Biol., 19 (2014) 76-81.

[4] P. Messina, E. Labbe, O. Buriez, E.A. Hillard, A. Vessieres, D. Hamels, S. Top, G. Jaouen, Y.M. Frapart, D. Mansuy, C. Amatore, Deciphering the activation sequence of ferrociphenol anticancer drug candidates, Chem. Eur. J., 18 (2012) 6581-6587.

[5] J.J. Soldevila-Barreda, P.J. Sadler, Approaches to the design of catalytic metallodrugs, Curr. Op. Chem. Biol., 25 (2015) 172-183.

[6] J.J. Soldevila-Barreda, I. Romero-Canelon, A. Habtemariam, P.J. Sadler, Transfer hydrogenation catalysis in cells as a new approach to anticancer drug design, Nature Commun., 6 (2015) 6582.

[7] J.M. Hearn, A.F. Miunro, I. Romero-Canelon, Y. Fu, A.M. Pizarro, M. Garnett, U. McDermott, N. Carrgher, P.J. Sadler, Potent organo-osmium compound shifts metabolism in epithelial ovarian cancer cells, Proc. Natl. Acad. Sci. U S A, 112 (2015) E3800 - E3805.

[8] F. Cisnetti, A. Gautier, Metal/N-Heterocyclic Carbene Complexes: Opportunities for the Development of Anticancer Metallodrugs, Angew. Chem. Int. Ed., 52 (2013) 11976-11978.

[9] M.A. Cinellu, I. Ott, A. Casini, in: G. Jaouen, M. Salmain (Eds.) Bioorganometallic Chemistry, Wiley-VCH2015, pp. 117-140.

[10] L. Oehninger, R. Rubbiani, I. Ott, N-Heterocyclic carbene metal complexes in medicinal chemistry, Dalton Trans., 42 (2013) 3269-3284.

[11] A.A. Nazarov, C.G. Hartinger, P.J. Dyson, Opening the lid on piano-stool complexes: An account of ruthenium(II)-arene complexes with medicinal applications, J. Organomet. Chem., 751 (2014) 251260.

[12] G. Gasser, I. Ott, N. Metzler-Nolte, Organometallic Anticancer Compounds, J. Med. Chem., 54 (2011) 3-25.

[13] C.G. Hartinger, N. Metzler-Nolte, P.J. Dyson, Challenges and Opportunities in the Development of Organometallic Anticancer Drugs, Organometallics, 31 (2012) 5677-5685. 
[14] M. Hanif, M.V. Babak, C.G. Hartinger, Development of anticancer agents: wizardry with osmium, Drug Discov. Today, 19 (2014) 1640-1648.

[15] Y. Fu, A. Habtemariam, A.M.B.H. Basri, D. Braddick, G.J. Clarkson, P.J. Sadler, Structureactivity relationships for organometallic osmium arene phenylazopyridine complexes with potent anticancer activity, Dalton Trans., 40 (2011) 10553-10562.

[16] Y. Fu, A. Habtemariam, A.M. Pizarro, S.H. van Rijt, D.J. Healey, P.A. Cooper, S.D. Shnyder, G.J. Clarkson, P.J. Sadler, Organometallic Osmium Arene Complexes with Potent Cancer Cell Cytotoxicity, J. Med. Chem., 53 (2010) 8192-8196.

[17] H.Z.S. Lee, W.K. Leong, S. Top, A. Vessieres, Cytotoxic Triosmium Carbonyl Clusters: A Structure-Activity Relationship Study, Chemmedchem, 9 (2014) 1453-1457.

[18] A. Nguyen, A. Vessieres, E.A. Hillard, S. Top, P. Pigeon, G. Jaouen, Ferrocifens and ferrocifenols as new potential weapons against breast cancer, Chimia, 61 (2007) 716-724.

[19] H.Z.S. Lee, O. Buriez, E. Labbe, S. Top, P. Pigeon, G. Jaouen, C. Amatore, W.K. Leong, Oxidative Sequence of a Ruthenocene-Based Anticancer Drug Candidate in a Basic Environment, Organometallics, 33 (2014) 4940-4946.

[20] E. Hillard, A. Vessieres, G. Jaouen, Ferrocene Functionalized Endocrine Modulators as Anticancer Agents, in: G. Jaouen, N. Metzler-Nolte (Eds.) Medicinal Organometallic Chemistry, Topics in Organometallic Chemistry, Springer, 2010, pp. 81-117.

[21] S.S. Braga, A.M.S. Silva, A New Age for Iron: Antitumoral Ferrocenes, Organometallics, 32 (2013) 5626-5639.

[22] G. Jaouen, S. Top, The Ferrocifen Family as Potent and Selective Antitumor Compounds: Mechanisms of Action, in: A.J.L. Pombeiro (Ed.) Advances in Organometallic Chemistry and Catalysis, Wiley \& Sons, 2014, pp. 563-580.

[23] C. Bruyere, V. Mathieu, A. Vessières, P. Pigeon, S. Top, G. Jaouen, R. Kiss, Ferrocifen derivatives that induce senescence in cancer cells selected examples. J. Inorg. Biochem., 141 (2014) 144-151.

[24] A. Vessieres, C. Corbet, J.M. Heldt, N. Lories, N. Jouy, I. Laios, G. Leclercq, G. Jaouen, R.A. Toillon, A ferrocenyl derivative of hydroxytamoxifen elicits an estrogen receptor-independent mechanism of action in breast cancer cell lines, J. Inorg. Biochem., 104 (2010) 503-511.

[25] A.-L. Lainé, A. Clavreul, A. Rousseau, C. Tétaud, A. Vessières, E. Garcion, G. Jaouen, L. Aubert, M. Guilbert, J.P. Benoit, R.A. Toillon, C. Passirani, Inhibition of ectopic glioma tumor growth by a potent ferrocenyl drug loaded into stealth lipid nanocapsules, Nanomedicine: NBM, 10 (2014) 16671677. 
[26] H.Z.S. Lee, O. Buriez, F. Chau, E. Labbe, R. Ganguly, C. Amatore, G. Jaouen, A. Vessieres, W.K. Leong, S. Top, Synthesis, characterization, and biological properties of osmium-based tamoxifen derivatives. Comparison with their homologues in the iron and ruthenium series, Eur. Inorg. Chem., 25 (2015) 4217-4226.

[27] D. Hamels, P.M. Dansette, E.A. Hillard, S. Top, A. Vessieres, P. Herson, G. Jaouen, D. Mansuy, Ferrocenyl Quinone Methides as Strong Antiproliferative Agents: Formation by Metabolic and Chemical Oxidation of Ferrocenyl Phenols, Angew. Chem., 48 (2009) 9124-9126.

[28] M.-A. Richard, D. Hamels, P. Pigeon, S. Top, P.M. Dansette, H.Z.S. Lee, A. Vessieres, D. Mansuy, G. Jaouen, Oxidative metabolism of ferrocene analogues of tamoxifen: characterization and antiproliferative activities of the metabolites, ChemMedchem, 10 (2015) 981-990.

[29] A. Bindoli, M.P. Rigobello, Principles in Redox Signaling: From Chemistry to Functional Significance, Antioxid. Redox Signal., 18 (2013) 1557-1593.

[30] S. Urig, K. Becker, On the potential of thioredoxin reductase inhibitors for cancer therapy, Semin. Cancer Biol., 16 (2006) 452-465.

[31] L. Johansson, G. Gafvelin, E.S.J. Arner, Selenocysteine in proteins - properties and biotechnological use, Biochim. Biophys. Acta, 1726 (2005) 1-13.

[32] A. Citta, A. Folda, A. Bindoli, P. Pascal Pigeon, S. Top, A. Vessières, M. Salmain, G. Jaouen, M.P. Rigobello, Evidence for targeting thioredoxin reductases with ferrocenyl quinone methides. A possible molecular basis for the antiproliferative effect of hydroxyferrocifens on cancer cells, J. Med. Chem., 57 (2014) 8849-8859.

[33] H. Liu, J. Liu, R.B. van Breemen, G.R.J. Thatcher, J.L. Bolton, Bioactivation of the selective estrogen receptor modulator desmethylated arzoxifene to quinoids: 4'-fluoro substitution prevents quinoid formation, Chem. Res. Toxicol., 18 (2005) 162-173.

[34] M. Luthman, A. Holmgren, rat-liver thioredoxin and thioredoxin reductase-purification and characterization, Biochemistry, 21 (1982) 6628-6633.

[35] O.H. Lowry, N.J. Rosebrough, A.L. Farr, R.J. Randall, Protein measurement with the Folin phenol reagent, J. Biol. Chem., 193 (1951) 265-275.

[36] S. Prast-Nielsen, M. Cebula, I. Pader, E.S.J. Arner, Noble metal targeting of thioredoxin reductase - covalent complexes with thioredoxin and thioredoxin-related protein of $14 \mathrm{kDa}$ triggered by cisplatin, Free Radic. Biol. Med., 49 (2010) 1765-1778.

[37] Y. Du, H. Zhang, X. Zhang, J. Lu, A. Holmgren, Thioredoxin 1 Is Inactivated Due to Oxidation Induced by Peroxiredoxin under Oxidative Stress and Reactivated by the Glutaredoxin System, J. Biol. Chem., 288 (2013) 32241-32247. 
[38] M.I. Rybinskaya, A.Z. Kreindlin, S.S. Fadeeva, On the problem of stabilization of alphacarbocationic centers in metallocene series-related interconversions of permethylated alphametallocenylcarbocations and metallicenium cation-radicals of the iron sub-group, J. Organomet. Chem., 358 (1988) 363-374.

[39] M.I. Rybinskaya, A.Z. Kreindlin, Y.T. Struchkov, A.I. Yanovsky, On the problem of stabilization of alpha-metallocenylcarbocation- synthesis, properties and crystal structures of $\mathrm{C}_{5} \mathrm{Me}_{5} \mathrm{OsC}_{5} \mathrm{Me}_{4} \mathrm{CH}_{2}{ }^{+}$ $\mathrm{BPh}_{4} \cdot \mathrm{CH}_{2} \mathrm{Cl}_{2}$, J. Organomet. Chem., 359 (1989) 233-243.

[40] C. Lu, J.-M. Heldt, M. Guille-Collignon, F. Lemaitre, G. Jaouen, A. Vessieres, C. Amatore, Quantitative Analyses of ROS and RNS Production in Breast Cancer Cell Lines Incubated with Ferrocifens, Chemmedchem, 9 (2014) 1286-1293. 


\section{Supplementary information}

\section{Osmocenyl-tamoxifen derivatives target the thioredoxin system leading to a redox imbalance in Jurkat cells}

Valeria Scalcon, ${ }^{\mathrm{a}, \mathrm{b}^{*}}$ Siden Top, ${ }^{\mathrm{c}, \mathrm{d}^{*}}$ Hui Zhi Shirley Lee, ${ }^{\mathrm{c}, \mathrm{d}, \mathrm{e}, \mathrm{f}}$ Anna Citta ${ }^{\mathrm{b}}$, Alessandra Folda ${ }^{\mathrm{b}}$, Alberto Bindoli, ${ }^{a}$ Weng Kee Leong, ${ }^{\mathrm{f}}$, Michèle Salmain, ${ }^{\mathrm{c}, \mathrm{d}}$, Anne Vessières, ${ }^{\mathrm{c}, \mathrm{d}}$ Gérard Jaouen, ${ }^{\mathrm{c}, \mathrm{d}, \mathrm{e}^{* *}}$ Maria Pia Rigobello, ${ }^{\mathrm{b} * *}$

a) Istituto di Neuroscienze (CNR) Sezione di Padova, c/o Dipartimento di Scienze Biomediche, Via Ugo Bassi 58/b, 35131 Padova, Italy.

b) Dipartimento di Scienze Biomediche, Università di Padova, Via Ugo Bassi 58/b, 35131 Padova, Italy.

c) Sorbonne Universités, UPMC Univ Paris 06, UMR 8232, IPCM, F-75005 Paris, France

d) CNRS, UMR 8232, IPCM, F-75005 Paris, France

e) Chimie ParisTech, 11 rue Pierre et Marie Curie, F-75005 Paris, France

f) Division of Chemistry \& Biological Chemistry, Nanyang Technological University, 21 Nanyang Ling, Singapore 637371 

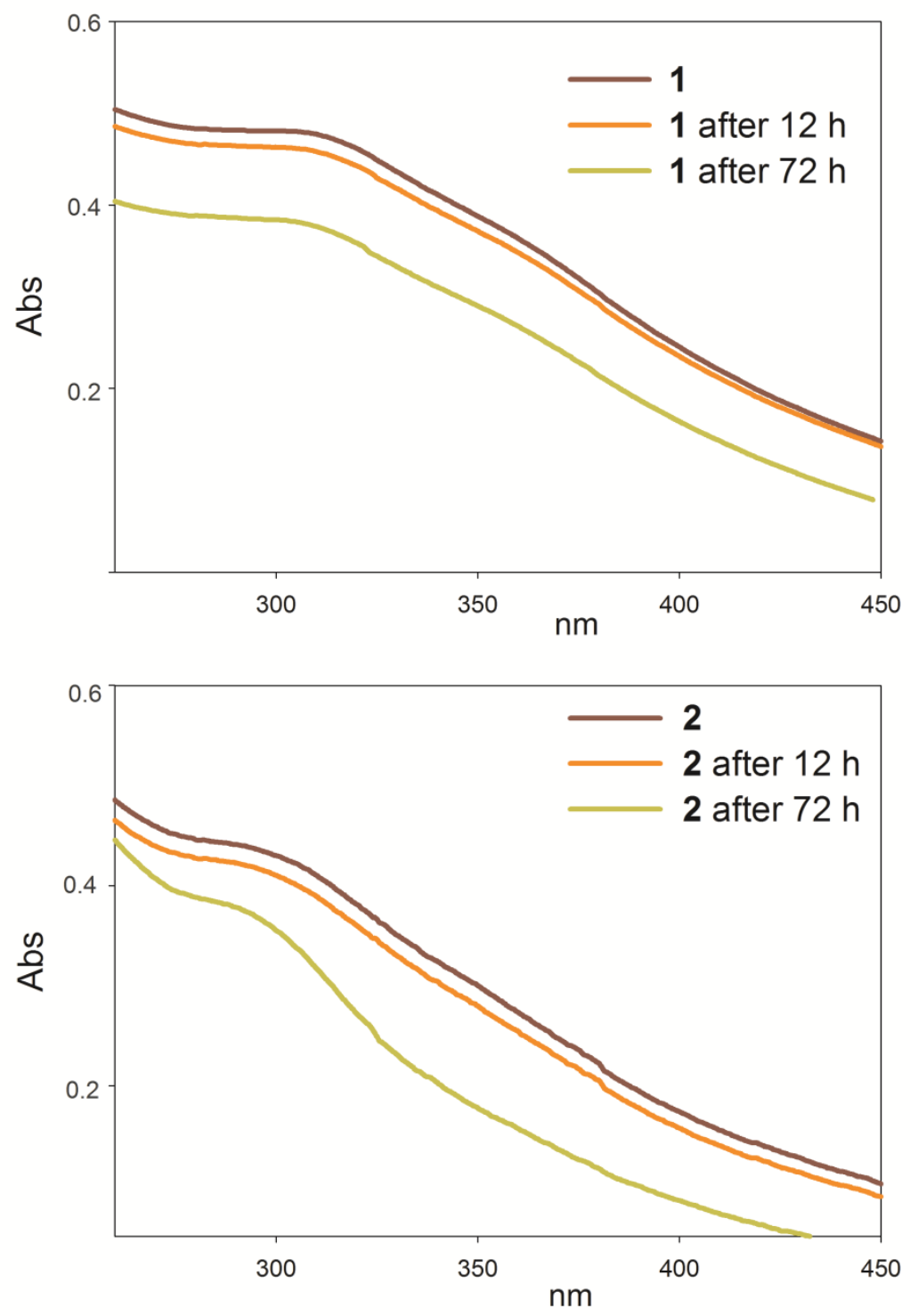

Fig. S1. UV-Vis spectra of 1 and $2(25 \mu M)$ in 0.2M Tris HCl buffer, pH 8.1. 


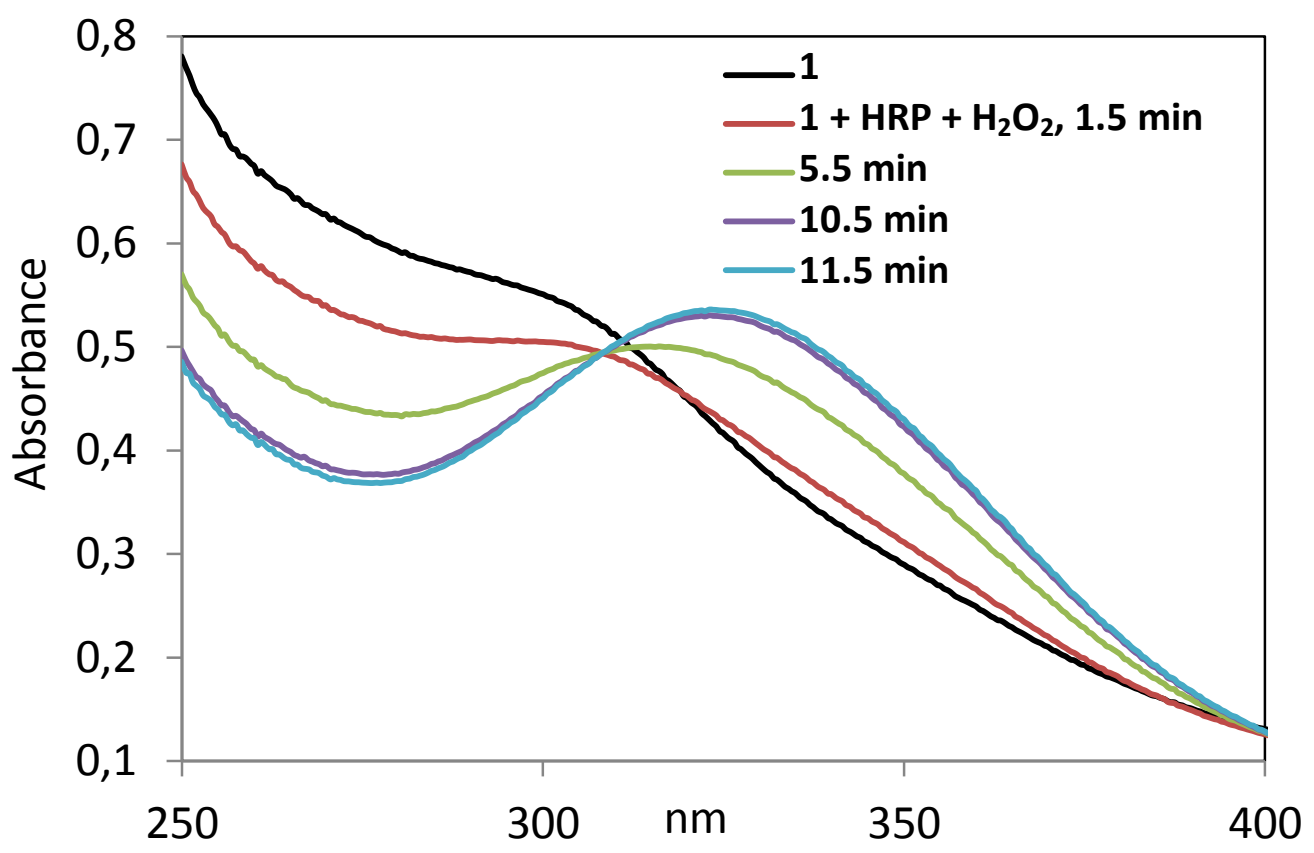

A

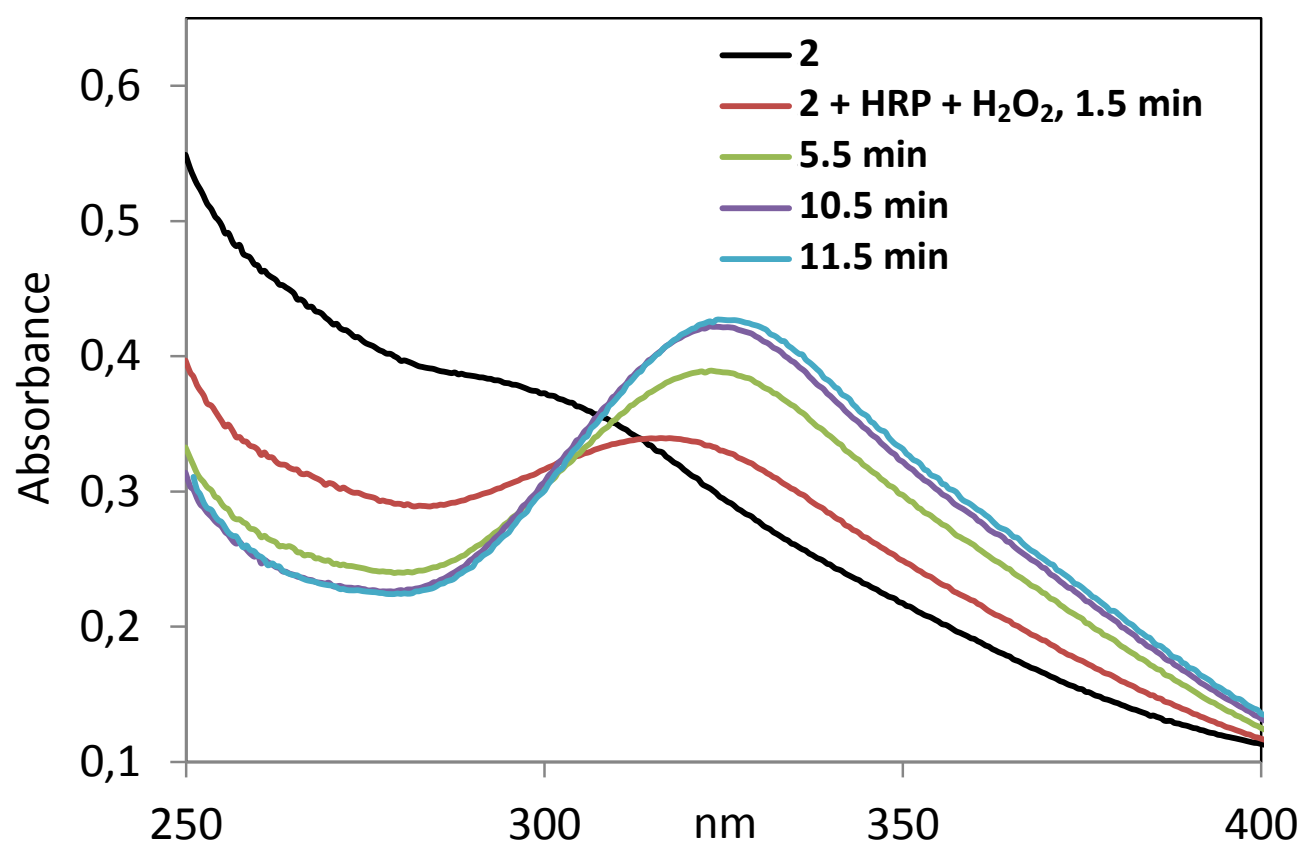

Fig. S2. UV-VIS spectra of 1 (A) and 2 (B) after treatment with $\mathrm{HRP}$ and $\mathrm{H}_{2} \mathrm{O}_{2}$.

Fresh solutions of 1 or 2 (25 $\mu \mathrm{M}$ in Tris HCl buffer (pH 8.1), 1 mM EDTA and 2.5\% DMSO) were incubated at $25{ }^{\circ} \mathrm{C}$ in the presence of $22 \mathrm{nM} \mathrm{HRP}+0.1 \mathrm{mM} \mathrm{H}_{2} \mathrm{O}_{2}$. Kinetics of the reactions after addition of $\mathrm{HRP}$ and $\mathrm{H}_{2} \mathrm{O}_{2}$ was followed by $U V$-VIS spectroscopy between 250 and $450 \mathrm{~nm}$, at different times from 1.5 to $11.5 \mathrm{~min}$. Black lines represent the spectra of 1 or 2 alone (before addition of HRP and $\mathrm{H}_{2} \mathrm{O}_{2}$ ). 


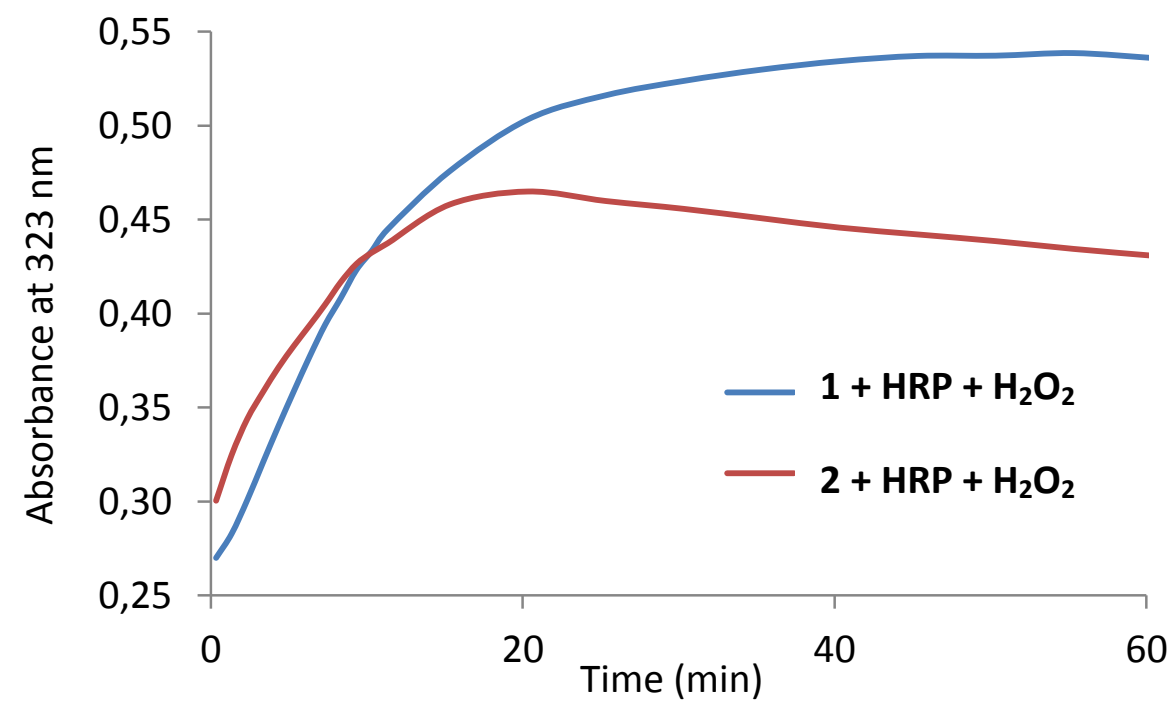

Fig. S3. Time-dependent formation and stability of $1 *$ and $2 *$, the complexes obtained by enzymatic oxidation of 1 and 2 by $\mathrm{HRP}+\mathrm{H}_{2} \mathrm{O}_{2}$. Formation of $\mathrm{I}^{*}$ and $2 *$ is monitored by the increase of absorbance at $323 \mathrm{~nm}$. Formation of $2 *$ is faster than that of $1 *$ (see Table S1). It reaches its maximum at 40 and 20 min respectively for $1 *$ and $2 * 1 *$ is stable during at least 60 min while $2 *$ is less stable $(7 \%$ decrease after $1 \mathrm{~h})$.

Table S1. Kinetics of formation of $1^{*}$ and $2^{*}$, the complexes obtained by enzymatic oxidation of $\mathbf{1}$ and $\mathbf{2}$ by HRP $+\mathrm{H}_{2} \mathrm{O}_{2}$. Comparison with the values obtained for 1-QM and 2-QM obtained by chemical oxidation of 1 and 2 with $\operatorname{Ag}_{2} \mathrm{O}$.

\begin{tabular}{|c|c|c|c|c|}
\hline complex & \multicolumn{2}{|c|}{ Kinetics of formation of $1^{*}$ or $2^{*}$} & \multicolumn{2}{|c|}{$\begin{array}{r}\text { Kinetics of formation of 2- } \\
\text { QM }\end{array}$} \\
\hline & $\mathrm{k}_{\mathrm{obs}}\left(\mathrm{min}^{-1}\right)$ & $\mathrm{t}_{1 / 2}(\mathrm{~min})$ & $\mathrm{k}_{\mathrm{obs}}\left(\min ^{-1}\right)$ & $\mathrm{t}_{1 / 2}(\mathrm{~min})$ \\
\hline $\mathbf{1}$ & $0.105 \pm 0.01^{\mathrm{c})}$ & $6.7 \pm 0.7^{\mathrm{c})}$ & - & - \\
\hline $\mathbf{2}$ & $0.18 \pm 0.02^{\mathrm{c})}$ & $4.0 \pm 0.4^{\mathrm{c})}$ & $0.029^{\mathrm{b})}$ & $24^{\mathrm{b})}$ \\
\hline
\end{tabular}

a) Obtained by enzymatic oxidation with $22 \mathrm{nM} \mathrm{HRP}$ and $0.1 \mathrm{mM} \mathrm{H}_{2} \mathrm{O}_{2}$ in Tris $\mathrm{HCl}(\mathrm{pH}$ 8.1), 1 mM EDTA. b) Obtained after chemical oxidation by $\mathrm{Ag}_{2} \mathrm{O}$; data from ref. [26]. c) Mean of two experiments. 


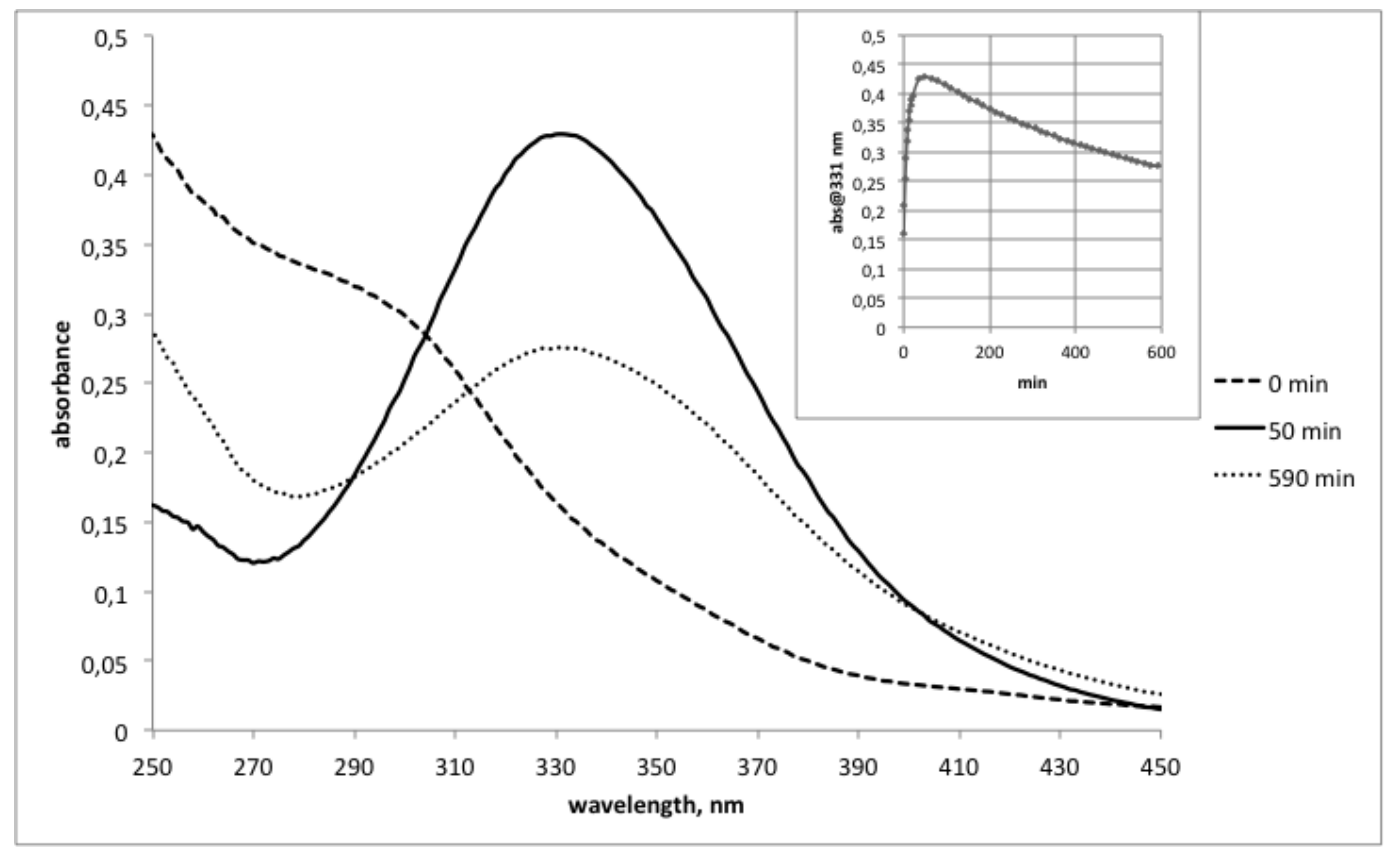

A

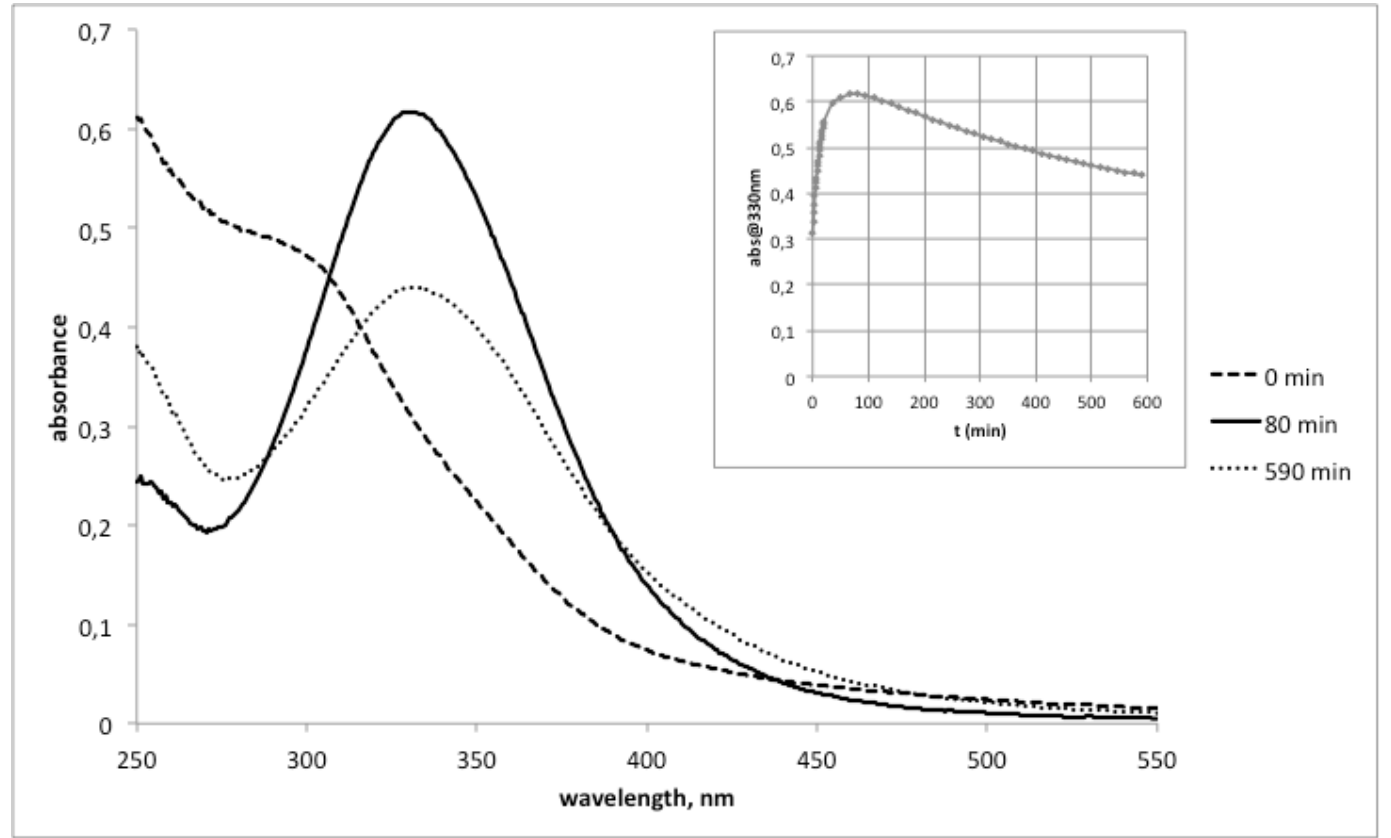

Fig. S4. UV-visible spectra of 1 (A) and $2(B)(25 \mu M)(t=0 \mathrm{~min})$, and of $1 *$ and $2 *$ obtained by incubation of 1 and 2 in the presence of $22 \mathrm{nM} \mathrm{HRP}$ and $0.1 \mathrm{mM} \mathrm{H}_{2} \mathrm{O}_{2}$ in $0.2 \mathrm{M} \mathrm{Tris} \mathrm{HCl}(\mathrm{pH} 8.1)$ ImM EDTA containing 2.5\% DMSO after 80 and 590 min. Inset: evolution of the absorbance at 330 nm as a function of time. 


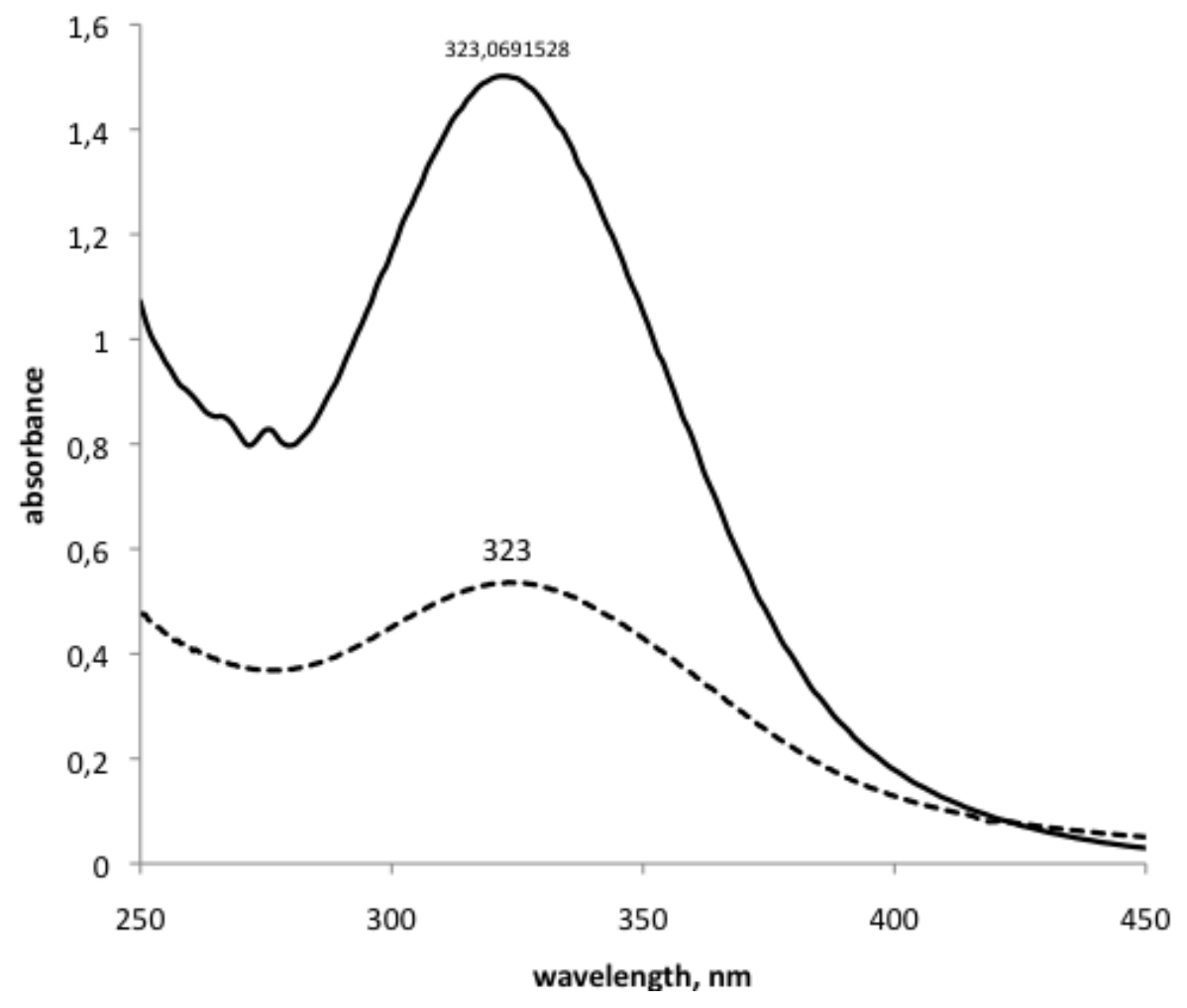

Fig. S5. Superimposition of the UV-VIS spectra of $1 *$ after precipitation with $\mathrm{NaBPh}_{4}$ and dissolution in $\mathrm{MeOH}$ (solid line) and of $1 *$ obtained under the experimental conditions of Fig. S2 (dashed line). 


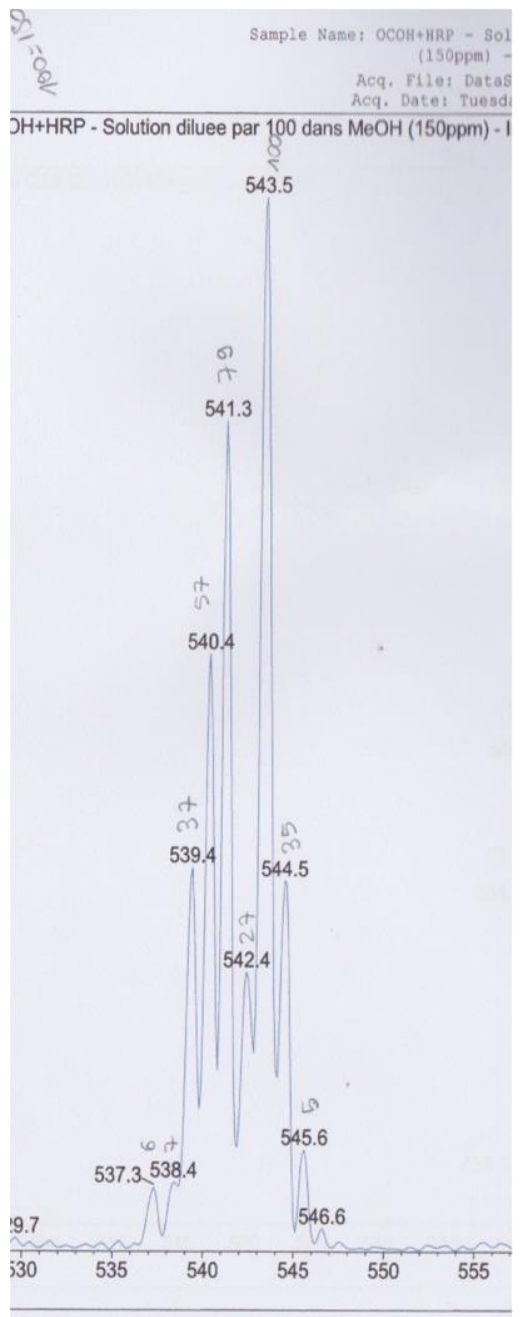

Experimental spectrum in the positive mode
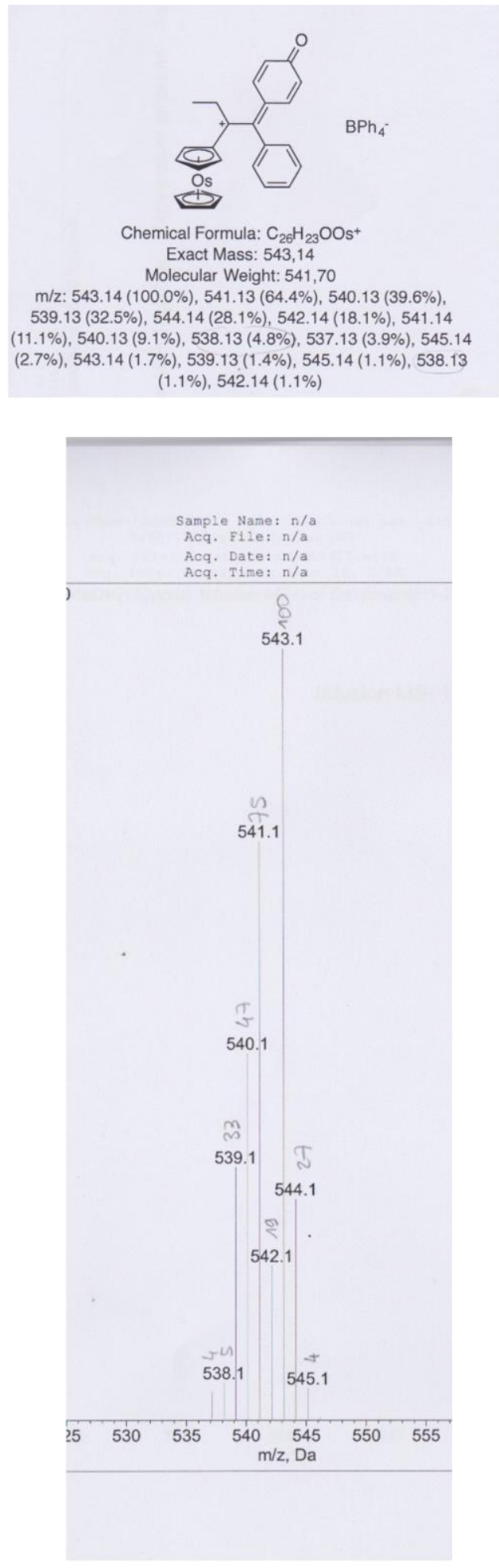

Calculated spectrum for [1-QM] $\mathrm{BH}_{4}$

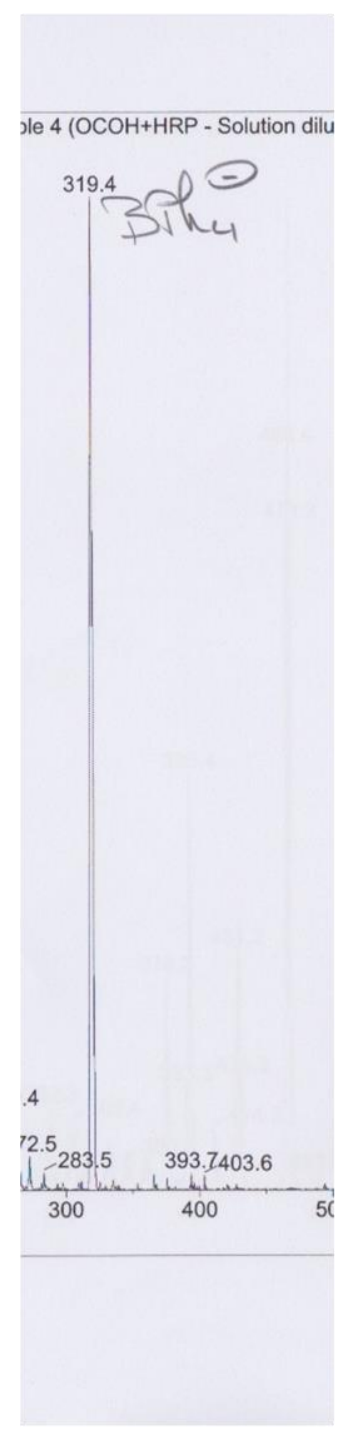

Experimental spectrum in the negative mode

Fig. S6. Analysis by mass spectrometry (ESI-MS analysis) of the precipitate obtained after treatment of 1 by $\mathrm{HRP}+\mathrm{H}_{2} \mathrm{O}_{2}$ followed by addition, after 20 min of $\mathrm{NaBPh}_{4}$. 
Table S2 : Quantification by ICP-OES of Osmium in $10^{7}$ Jurkat cells after 24 h of incubation

\begin{tabular}{ccccc}
\hline Compound & $\begin{array}{c}\text { Amount of Os in the } \\
\text { sample (in ppb) }\end{array}$ & $\begin{array}{c}\text { Amount of Os in } \\
10^{7} \text { cells (in nmol) }\end{array}$ & $\begin{array}{c}\text { Amount of Os per cell } \\
\text { (fmol) }\end{array}$ & $\begin{array}{c}\text { LogPo/w } \\
\end{array} \mathbf{1}^{\text {b) }}$ \\
$2^{\text {c) }}$ & $796 \pm 6$ & 38.7 & 3.9 & 6.3 \\
& $855 \pm 5$ & 41.6 & 4.2 & 4.3
\end{tabular}

a) mean of 3 measurements, control $<50 \mathrm{ppb}$, analysis performed on a volume of $9.25 \mathrm{~mL} ; b$ ) concentration of incubation of $1: 50 \mu \mathrm{M}$; c) concentration of incubation $2: 15 \mu \mathrm{M}$; d) value from ref [26] 


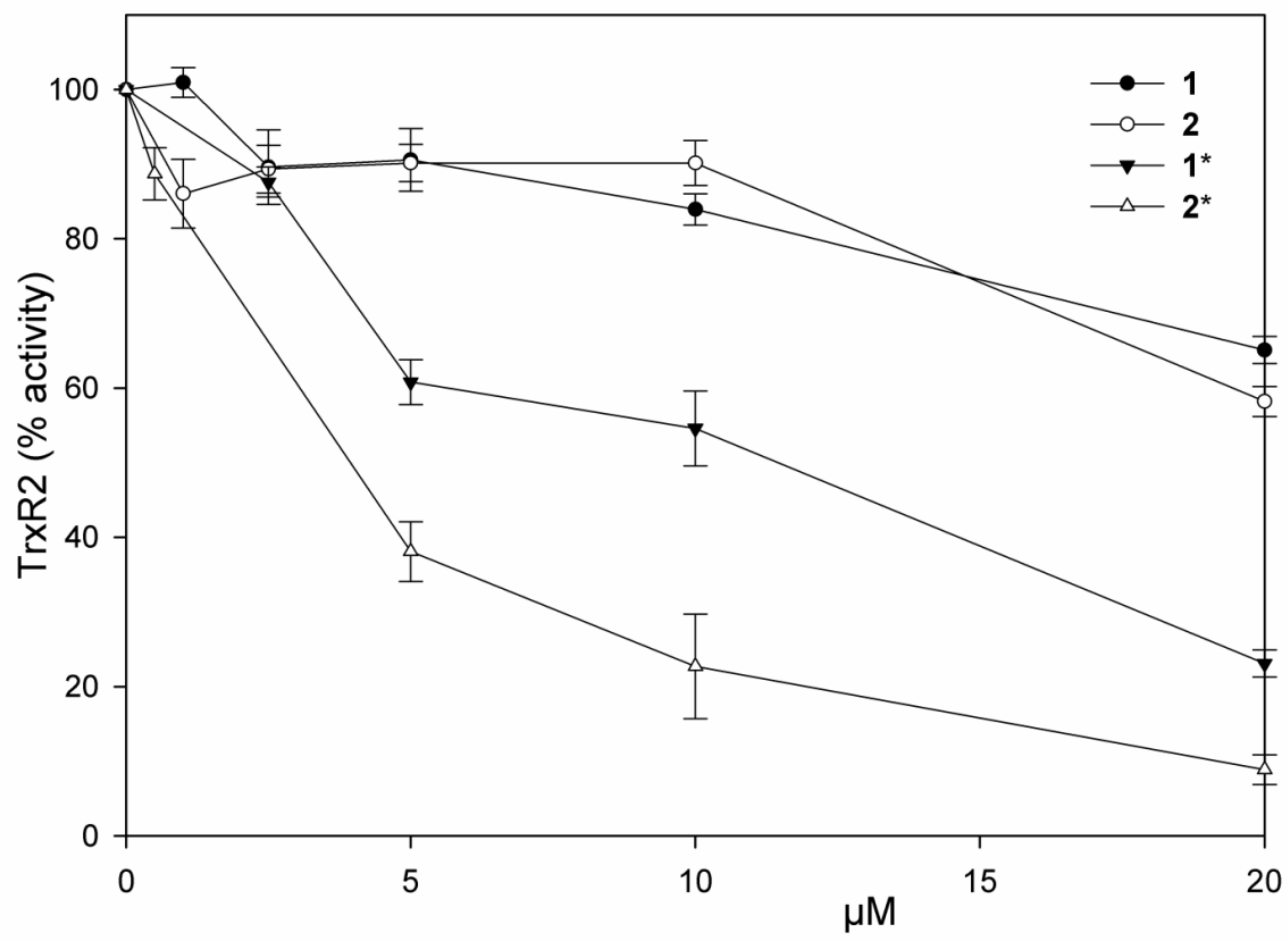

Fig. S7. Thioredoxin reductase 1 (TrxR1) inhibition with osmocifens.

1, 2 and the compounds obtained after pre-treatment for 15 min of 1 and 2 with $0.1 \mathrm{mM} \mathrm{H}_{2} \mathrm{O}_{2}$ and 22 $n M \operatorname{HRP}\left(1^{*}, 2^{*}\right)$, were incubated in $0.2 \mathrm{M}$ Tris $\mathrm{HCl}$ buffer (pH 8.1) and $1 \mathrm{mM}$ EDTA with 0. $25 \mathrm{mM}$ NADPH and 60 nM TrxR1. After 5 min, TrxR1 activity was estimated as described in Materials and methods. Under the same experimental conditions the $\mathrm{HRP} / \mathrm{H}_{2} \mathrm{O}_{2}$ mixture is ineffective on TrxRl activity in the absence of osmocifen compounds. 


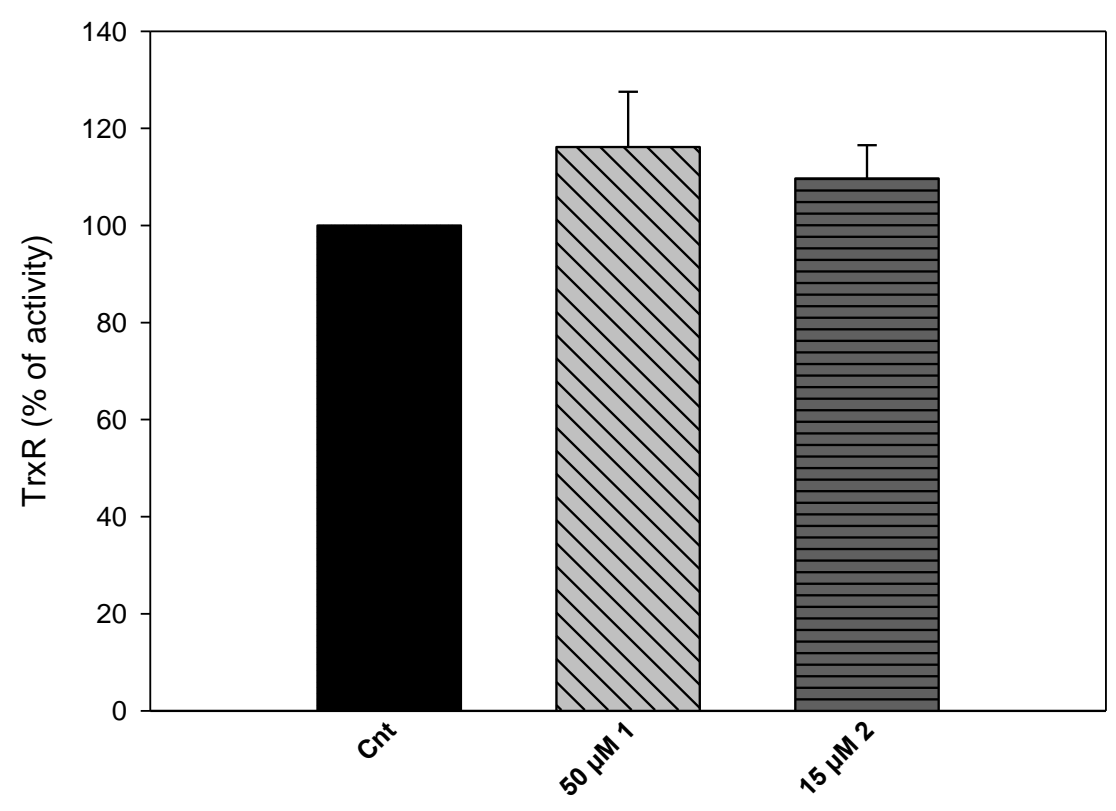

Fig. S8. Effect of compounds 1 and 2 on TrxR activity in HEK293 cell lysates. $1 \times 10^{6}$ cells were treated with the indicated concentrations of 1 and $\mathbf{2}$ for $18 \mathrm{~h}$. Cell lysates were tested for thioredoxin reductase activity with the DTNB procedure as described in Materials and methods. 